\title{
Dominantna načela i modeli tretmanskog rada s punoljetnim počiniteljima kaznenih djela u zajednici
}

\author{
Snježana Maloić \\ Ministarstvo pravosuđa, Uprava za kazneno pravo i probaciju, Sektor za \\ probaciju - Središnji ured
}

Sažetak

\begin{abstract}
Rad uvodno donosi prikaz probacijskih poslova u Hrvatskoj, od kojih velik broj podrazumijeva i tretmanski rad s počiniteljima kaznenih djela. U okviru rehabilitacijskog pristupa hrvatska probacijska služba slijedi načela Modela rizik-potreba-responzivnost (RPR model), a u određenoj mjeri i načela Modela kvalitetnih života (MKŽ-a). U ovom se radu RPR model analizira sa stajališta postojećih prednosti i kritika, pri čemu se posebno razmatra načelo responzivnosti, koje se u stranoj literaturi ističe naročito izazovnim. Nakon kratkog prikaza MKŽ-a, slijedi usporedba ova dva modela, čija načela aktualno dovode do velikih rasprava zbog potencijalnih razlika u pristupima počinitelju kaznenog djela. Modeli i pripadajuća načela se potom analiziraju sa stajališta izazova njihove primjene u obavljanju probacijskih poslova. Provedene analize mogu pridonijeti učinkovitosti rada hrvatske probacijske službe, a mogu biti od koristi i znanstvenicima, pri validaciji probacijskog aktuarskog instrumenta i istraživanju domaće probacijske prakse.
\end{abstract}

Ključne riječi: probacija, rehabilitacija, načela, Model rizik-potreba-responzivnost, Model kvalitetnih života

\section{Uvod}

Na međunarodnoj razini, rad s počiniteljima kaznenih djela u zajednici kao izraženije prisutna tema pojavljuje se ranih 90-ih godina 20. stoljeća. Ujedinjeni narodi i Vijeće Europe u tom su razdoblju intenzivnije usmjeravali prema većem korištenju probacijskih mjera i sankcija, dok se istovremeno nastojalo uspostaviti minimalne međunarodne standarde u svrhu osiguranja poštivanja ljudskih prava (Morgenstern i Larrauri, 2013; Kovčo Vukadin, Rajić i Balenović, 2009). Vijeće Europe se aktivno uključilo u ovu problematiku i kroz Europska probacijska pravila 2010. godine1, koja predstavljaju i svojevrstan vodič i standarde za uspostavu i pravilno funkcioniranje probacijskih službi (Kovčo Vukadin, Rajić i Maloić, 2011).

Analizirajući razvoj probacijskih sankcija u Hrvatskoj, možemo vidjeti da su se prve takve sankcije počele izvršavati krajem 2001. godine, u organizaciji zatvorskog sustava (Rajić, Maloić i Knotek-Iveta, 2005; Kokić Puce i Kovčo Vukadin, 2006). U domaćoj literaturi iz tog razdoblja one se uglavnom nazivaju nezatvorskim odnosno alternativnim sankcijama. Prvi je Zakon o probaciji (NN, 153/09) donesen 2009. godine, od kada se i u našoj zemlji počinje intenzivnije govoriti o probacijskim mjerama i sankcijama (Kovčo Vukadin, Rajić i Maloić, 2011; Maloić i Rajić, 2012). Kako su prvi probacijski uredi u Hrvatskoj započeli s radom u lipnju 2011. godine, sada već možemo govoriti o petogodišnjem funkcioniranju hrvatske profesionalne probacijske službe. Pri tome ipak treba imati

1 Recommendation CM/Rec (2010)1 of the Committee of Ministers to member states on the Council of Europe Probation Rules (Adopted by the Committee of Ministers on 20 January 2010 at the 1075th meeting of the Ministers' Deputies) 
u vidu da je probacijski ured u Dubrovniku s radom započeo tek u siječnju 2013. godine (Maloić i Šimpraga, 2014). Uvidom u dostupne statističke podatke, razvidno je da broj predmeta probacijske službe kontinuirano raste - prikazano Tablicom 1. (Ministarstvo pravosuđa RH, 2014; Ministarstvo pravosuđa RH, 2015a; Ministarstvo pravosuđa RH, 2016).

Tablica 1 Broj predmeta probacijske službe (Ministarstvo pravosuđa RH, 2014; Ministarstvo pravosuđa RH, 2015a; Ministarstvo pravosuđa RH, 2016)

\begin{tabular}{|l|c|c|c|c|}
\hline \multicolumn{1}{|c}{ Predmeti } & \multicolumn{3}{c|}{ Godina } \\
\cline { 2 - 5 } & $\mathbf{2 0 1 2}$ & $\mathbf{2 0 1 3 .}$ & $\mathbf{2 0 1 4 .}$ & $\mathbf{2 0 1 5 .}$ \\
\hline Zaprimljeni tijekom godine & 1573 & 3304 & 3618 & 3911 \\
\hline U radu na dan 31. prosinca & 2059 & 2907 & 3019 & 3255 \\
\hline Završeni tijekom godine & 1145 & 3313 & 3572 & 3756 \\
\hline
\end{tabular}

lako su klijenti pojedinih stranih probacijskih službi i maloljetnici i žrtve kaznenih djela, hrvatska probacijska služba radi isključivo s punoljetnim počiniteljima kaznenih djela. Pri tome surađuje s različitim državnim institucijama i nevladinim organizacijama, prvenstveno s policijom, zatvorskim sustavom i sustavom socijalne skrbi (Maloić i Rajić, 2012; Kovčo Vukadin, Maloić i Rajić, 2012; Ministarstvo pravosuđa RH, 2014; Maloić, Rajić i Mažar, 2015). Probacijski se poslovi u Hrvatskoj obavljaju na zahtjev državnog odvjetnika, suda, suca izvršenja ili kaznionice odnosno zatvora, a propisani su člankom 10. st. 1. Zakona o probaciji (NN, 143/12). Možemo ih podijeliti u dvije skupine: (1) poslovi kojima se kod donošenja odluka nadležnom tijelu dostavljaju informacije o počinitelju kaznenog djela i specifičnim okolnostima i (2) poslovi koji podrazumijevaju neposredan rad probacijske službe s počiniteljem. Ova osnovna podjela probacijskih poslova prezentirana je kroz Tablični prikaz 1.

Tablica 2 Osnovna podjela probacijskih poslova (probacijski poslovi prema čl. 10. st. 1. Zakona o probaciji $(N N, 143 / 12)$

\begin{tabular}{|c|c|}
\hline Izrada izvješća & $\begin{array}{l}\text { Izvršavanje obveza/mjera/sankcija - neposredan rad } \\
\text { probacijske službe s počiniteljem }\end{array}$ \\
\hline $\begin{array}{l}\text { - na traženje državnog odvjetnika kada odlučuje o kaznenom } \\
\text { progonu prema načelu svrhovitosti } \\
\text { - } \text { na zahtjev suda kod određivanja mjera osiguranja prisutnosti } \\
\text { okrivljenika i mjera opreza } \\
\text { - } \text { na zahtjev suda kod izbora vrste i mjere kaznenopravne } \\
\text { sankcije } \\
\text { - na traženje zatvora, odnosno kaznionice kod odlučivanja o } \\
\text { pogodnostima izlaska } \\
\text { - - na zahtjev suda u postupku odlučivanja o prekidu izvršavanja } \\
\text { kazne zatvora te uvjetnom otpustu }\end{array}$ & $\begin{array}{l}\text { - nadzor izvršavanja obveza prema rješenju državnog odvjetnika } \\
\text { - izvršavanje zaštitnog nadzora izrečenog uz uvjetnu osudu, } \\
\text { rad za opće dobro, uvjetni otpust i po punom izvršenju kazne } \\
\text { zatvora } \\
\text { - pribavljanje pristanka na zamjenu kazne zatvora radom za opće } \\
\text { dobro te organiziranje i nadziranje izvršavanja rada za opće } \\
\text { dobro, } \\
\text { - nadzor uvjetno otpuštenog osuđenika } \\
\text { - organiziranje i nadziranje izvršavanja posebnih obveza iz } \\
\text { Kaznenog zakona (NN, 125/11, 144/12, 56/15, 61/15) te obveza } \\
\text { iz Zakona o kaznenom postupku }(\mathrm{NN}, 152 / 08,76 / 09,80 / 11, \\
\text { 121/11, } 91 / 12,143 / 12,56 / 13,145 / 13,152 / 14) \text {. }\end{array}$ \\
\hline
\end{tabular}

Probacijska služba sudjeluje u svim fazama kaznenog postupka i izvršavanja sankcija i mjera, na način prikazan Slikom 1., sukladno ključnim zakonskim propisima - Kaznenom zakonu, (NN, 125/11, 144/12, 56/15, 61/15), Zakonu o kaznenom postupku (NN, 152/08, 76/09, 80/11, 121/11, 91/12, 143/12, 56/13, 145/13, 152/14) i Zakonu o probaciji (NN, 143/2012). 
Snježana Maloić: Dominantna načela i modeli tretmanskog rada s punoljetnim počiniteljima kaznenih djela...

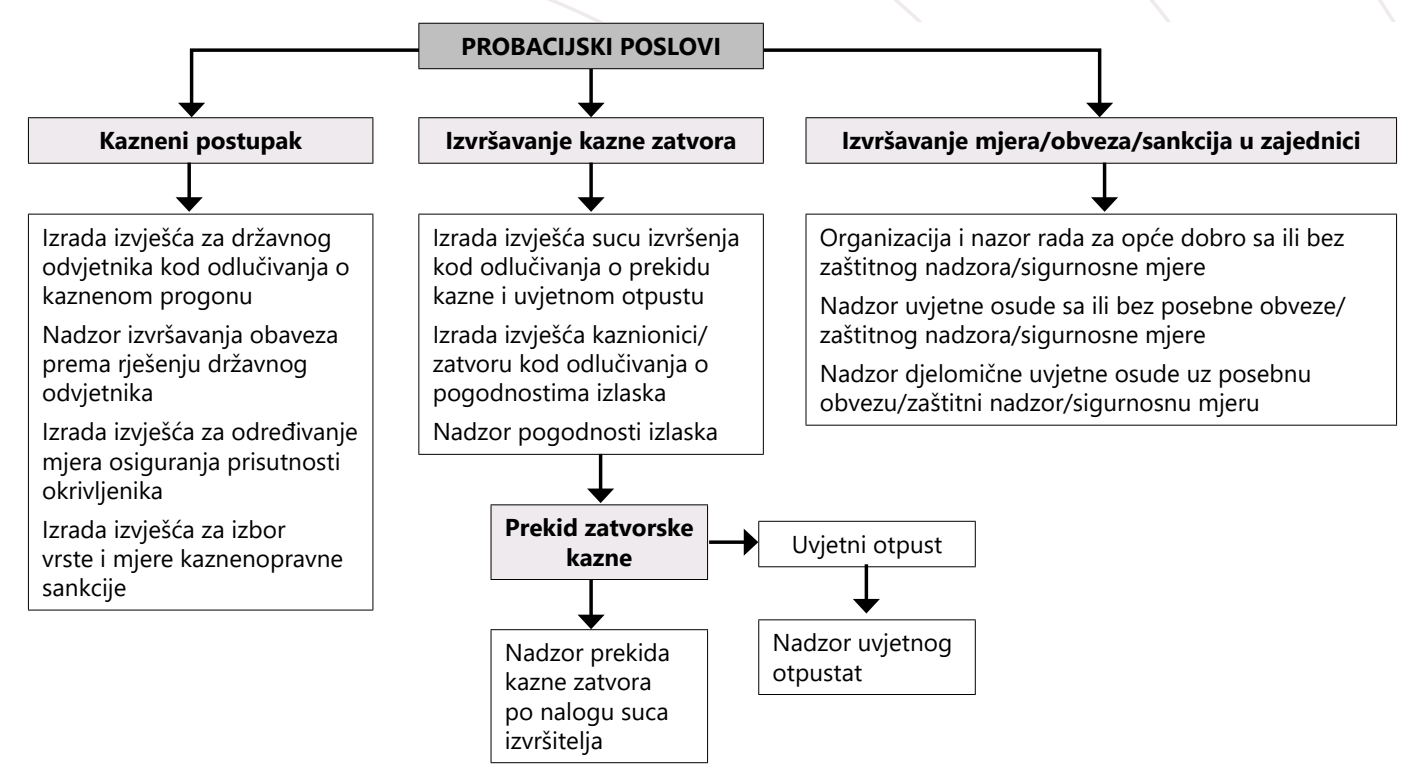

Slika 1 Shematski prikaz probacijskih poslova u RH po fazama kaznenog postupka $i$ izvršavanja sankcija, prema Kaznenom zakonu, (NN, 125/11, 144/12, 56/15, 61/15), Zakonu o kaznenom postupku (NN, 152/08, 76/09, 80/11, 121/11, 91/12, 143/12, 56/13, 145/13, 152/14) i Zakonu o probaciji (NN, 143/2012).

Probacijski poslovi čije izvršavanje zahtijeva neposredan rad s počiniteljem, uvijek podrazumijevaju i određene tretmanske intervencije, makar i u minimalnom intenzitetu (primjerice, usmjeravanje, motiviranje). Kod pojedinih sankcija kao što je rad za opće dobro na slobodi prisutniji je organizacijski aspekt rada probacijske službe, dok je kod izvršavanja obveze/posebne obveze određenog ponašanja i/ili zaštitnog nadzora, izrečenih uz pojedinu sankciju (primjerice, uvjetnu osudu ili uvjetni otpust), dominantniji tretmanski rad s počiniteljem (Maloić, 2015). Posljednjim izmjenama Kaznenog zakona (NN, 56/2015), kao probacijski poslovi propisani su i izvršavanje sigurnosnih mjera liječenja od ovisnosti, psihijatrijskog liječenja i psihosocijalnog tretmana nasilja izrečenih uz uvjetnu osudu, rad za opće dobro na slobodi i novčanu kaznu, a što će se dodatno regulirati i očekivanim izmjenama sada važećeg Zakona o probaciji (NN, 143/12). Ove su sigurnosne mjere u potpunosti tretmanski usmjerene.

Probacijski poslovi se u Hrvatskoj - prema čl. 2. st. 1. Zakona o probaciji (NN, 143/2012) obavljaju s ciljem zaštite društvene zajednice od počinitelja kaznenog djela, njegove resocijalizacije i reintegracije u zajednicu, utjecanjem na rizične čimbenike koji su povezani s činjenjem kaznenih djela. Temeljem dostupnih dokumenata možemo zaključiti kako hrvatska probacijska služba podjednako stavlja naglasak i na zaštitu zajednice i na socijalnu integraciju počinitelja kaznenog djela (Ministarstvo pravosuđa RH, 2014; Ministarstvo pravosuđa RH, 2015a). U obavljanju probacijskih poslova koji podrazumijevaju tretmanski rad, služba slijedi načela prakse utemeljene na dokazima (eng. evidence based practice), odnosno nastoji primjenjivati pristupe, modele i tehnike koji su prema rezultatima znanstvenih istraživanja učinkoviti u smanjenju recidivizma (Maloić i Mažar, 2014; Ministarstvo pravosuđa RH, 2015a). Dakle, probacijska služba svoje poslove obavlja slijedeći Što funkcionira? (eng. What works?) pristup i u svom radu prvenstveno prati načela Modela rizik-potreba-responzivnost to jest RPR modela (engl. Risk - need - responsivity model, RNR Model) (Ministarstvo pravosuđa RH, 2015b). Do određene mjere služba nastoji uvažavati i paradigmu 
prestanka i odvraćanja od činjenja kaznenih djela (eng. desistance paradigm) i Model kvalitetnih života, MKŽ (eng. Good lives model, GLM Model) (Šimpraga, Maloić i Ricijaš, 2014). Hrvatski probacijski službenici su o osnovama RPR modela, a djelomice i o MKŽ-u, educirani kroz EU projekt Razvoj probacijskog sustava u Republici Hrvatskoj- Twinning projekt, koji se provodio od lipnja 2011. godine do ožujka 2013. godine (Maloić i Ricijaš, 2014).

Pregledom domaće literature možemo vidjeti da su načela RPR modela privukla pozornost naših znanstvenika i stručnjaka (Mikšaj-Todorović, Buđanovac i Brgles, 1998; Nikolić, Koller-Trbović i Žižak, 2002; Ricijaš, 2006; Ricijaš, 2009a; Kovčo, Rajić i Balenović, 2009; Koller-Trbović, Nikolić i Ratkajec Gašević, 2010; Radetić-Paić, 2010; Kovčo, Rajić i Maloić, 2011; Mejovšek, 2013). Ipak, činjenica je da u domaćoj literaturi nedostaje sveobuhvatna analiza modela, s gledišta njegovih prednosti i kritika, a naročito vezano uz njegovu primjenu u radu s punoljetnim počiniteljima kaznenih djela u zajednici. U ovom će se radu RPR model stoga analizirati kao cjelovit model koji se nudi u rehabilitaciji punoljetnih počinitelja kaznenih djela, pri čemu će se posebno razmatrati načelo responzivnosti koje se u stranoj literaturi ističe naročito izazovnim. Nakon kratkog prikaza MKŽ-a, slijedi usporedba ova dva modela, čija načela aktualno dovode do velikih rasprava zbog potencijalnih razlika u pristupima počinitelju kaznenog djela. Modeli i pripadajuća načela će se potom analizirati i sa stajališta izazova njihove primjene u obavljanju probacijskih poslova. Provedene analize mogu pridonijeti učinkovitosti rada hrvatske probacijske službe, a mogu biti od koristi i znanstvenicima, pri validaciji probacijskog aktuarskog instrumenta i istraživanju domaće probacijske prakse.

Uvodno je važno napomenuti i da pojedine probacijske službe primjenjuju još neke modele, od kojih je najpoznatiji model restorativne pravde u Češkoj (Jelínek i Matoušková, 2015). No, zbog ograničenog obima ovog rada, još uvijek ograničenog broja istraživanja češkog modela i činjenice da hrvatska legislativa zasad ne daje ovlasti probacijskoj službi u tom smjeru, taj se model kroz ovaj rad neće pobliže analizirati.

\section{Značajke modela rizik-potreba-responzivnost i njegova (ne)prihvaćenost u svijetu}

Model rizik-potreba-responzivnost je nastao temeljem niza istraživanja koja se posljednjih dvadeset godina provode u okviru paradigme Što funkcionira?. Ova je paradigma nastala kao reakcija na Martinsonove tvrdnje 1974. godine i smjer Ništa ne funkcionira (eng. Nothing works) u rehabilitaciji počinitelja kaznenih djela. Taj je pesimističan smjer izazvao velike sumnje u moguću učinkovitost rehabilitacijskih intervencija prema počiniteljima kaznenih djela, sa značajnim negativnim učinkom na pristupe kažnjavanju u mnogim zemljama (Ward, Melser i Yates, 2007; Latessa i sur., 2013; Maloić, 2013; Labrecque, Schweitzer i Smith, 2014). Stoga se istraživanjima nastoji prepoznati i potvrditi uvjete koje bi trebale ispunjavati učinkovite rehabilitacijske strategije odnosno intervencije u suzbijanju recidivizma (Schwalbe, 2012). Andrews, Bonta i Howge su 1990. godine (prema Bourgon i Bonta, 2014), dakle u samim začecima razvoja RPR modela, predstavili četiri načela. Prva su tri trebala odgovoriti na pitanja tko?, što?, i kako?, dok se četvrtim načelom pozivalo na profesionalnu diskreciju (eng. professional discretion), u slučajevima kad se ponašanje ne bi moglo objasniti postojećim spoznajama unutar ovog modela. Kada se u kontekstu RPR modela govori o profesionalnoj diskreciji, zapravo se misli na postojanje prostora za diskrecijsku 
odluku stručnjaka, kako kod procjene rizika, potreba i responzivnosti, tako i u odabiru tretmanskih intervencija. Stoga ćemo u nastavku rada u tom smislu govoriti o mogućnosti diskrecijske odluke stručnjaka. Relativno brzo nakon predstavljanja ovih načela, autori uvode i peto načelo kojim se naglasak stavlja na integritet programa. Tim se načelom nastojalo osigurati primjenu programa $u$ praksi na način kako je to teorijski i provedbeno inicijalno zamišljeno, nakon što je istraživanjima primjene modela u praksi uočeno da se programi nerijetko provode pojednostavljeno i parcijalno (Andrews i Bonta, 2003, prema Wood, Kade i Sidhu, 2009).

Pregledom dostupne literature možemo vidjeti da je danas u percepciji i prezentaciji ovog modela naglasak najčešće na tri načela: rizika, potreba i responzivnosti - Tablični prikaz 3., ili se uobičajeno govori o konceptu rizika i potreba (Clark, 2005; Ward, Melser i Yates, 2007; Wood, Kade i Sidhu, 2009; Cullen, 2012; Bourgon i Bonta, 2014).

Tablica 3 Tri temeljna načela Modela rizik-potreba-responzivnost (Clark, 2005; Bourgon i Bonta, 2014).

\begin{tabular}{|l|l|}
\hline NAČELA & \multicolumn{1}{c|}{ SADRŽAJ NAČELA } \\
\hline Procjena kriminogenog rizika & $\begin{array}{l}\text { Smatra se da intenzitet tretmana treba odgovarati razini procijenjenog rizika, pri čemu } \\
\text { najveći broj i intenzitet intervencija treba biti usmjeren prema najrizičnijim počiniteljima. }\end{array}$ \\
\hline $\begin{array}{l}\text { Usmjerenost na kriminogene } \\
\text { potrebe }\end{array}$ & $\begin{array}{l}\text { Naglašava se da tretmanski ciljevi trebaju proizlaziti iz kriminogenih potreba, to jest potreba } \\
\text { funkcionalno povezanih s činjenjem kaznenih djela. Dakle, tretmanske intervencije je } \\
\text { potrebno usmjeriti prema dinamičkim čimbenicima rizika. }\end{array}$ \\
\hline Uvažavanje responzivnosti & $\begin{array}{l}\text { Pri odabiru i provođenju tretmanskih intervencija, u svrhu osiguravanja učinkovitosti } \\
\text { tretmana, nužno je uvažavati čimbenike responzivnosti koji se odnose na osobna obilježja } \\
\text { počinitelja i na kontekstualna obilježja. }\end{array}$ \\
\hline
\end{tabular}

Ovim se modelom smatra da je vjerojatnost ponovnog počinjenja kaznenog djela moguće predvidjeti, da postoje brojni čimbenici koji kod počinitelja mogu predstavljati rizik za kriminalni povrat i da je te čimbenike moguće prepoznati i na njih djelovati (Cullen, 2012). Rizične čimbenike možemo najjednostavnije definirati kao životne događaje ili osobine koji doprinose razvoju nekog poremećaja ili delinkventnog ponašanja (Wilson i Rolleston, 2004, prema Ricijaš, 2009a). Neki od tih čimbenika se ne mogu promijeniti (npr. povijest kriminalnog ponašanja) pa se stoga nazivaju statičkim čimbenicima; neki se mogu mijenjati te se sukladno tome govori o dinamičkim čimbenicima iz kojih proizlaze kriminogene potrebe, odnosno potrebe tretmana (tretmanskih intervencija) (npr. smještaj) (Cullen, 2012).

RPR model je izazvao svojevrsnu revoluciju u načinima odgovora na kriminalno ponašanje u Kanadi, Australiji i Novom Zelandu (Ward, Melser i Yates, 2007). Kanadski korekcijski sustav je devedesetih godina 20. stoljeća u potpunosti prihvatio koncept kriminogenih rizika i potreba kao relativno unificiran model - najprije u sankcioniranju odraslih počinitelja kaznenih djela (Ricijaš, 2006). Ovaj je koncept zatim relativno brzo prihvaćen u Velikoj Britaniji, dok se aktualno zamjećuje opća tendencija njegovog prihvaćanja u europskim zemljama (Bourgon i Bonta, 2014; Melton i sur., 2014).

U novije se vrijeme sve više nailazi na radove kojima se ukazuje na manjkavosti RPR modela - najčešće kritike prezentirane su Tabličnim prikazom 4. (Ward, Melser i Yates, 2007; Matthews, 2009; Maloić i Rajić, 2012; Boone, 2016): 
Tablica 4 Najčešće kritike Modela rizik-potreba-responzivnost (Ward, Melser i Yates, 2007; Matthews, 2009; Maloić i Rajić, 2012; Boone, 2016)

\begin{tabular}{|c|c|}
\hline \multicolumn{2}{|c|}{ NAJČEŠĆE KRITIKE MODELA RIZIK-POTREBA-RESPONZIVNOST } \\
\hline $\begin{array}{l}\text { Naglasak na procjeni i upravljanju } \\
\text { rizikom }\end{array}$ & $\begin{array}{l}\text { Radi se o psihometrijskom modelu usmjerenom na izradu profila rizika počinitelja } \\
\text { (odnosno prijetnji koje on predstavlja), pri čemu se umanjuje značaj konceptualnih i } \\
\text { ekoloških čimbenika u rehabilitaciji počinitelja. Model ne predstavlja integriranu teoriju i } \\
\text { tri glavna načela nisu dovoljno teorijski utemeljena. }\end{array}$ \\
\hline Usmjerenost na intervenciju & $\begin{array}{l}\text { Naglasak je na pružanju „uniformnih“, empirijski dokazanih, strukturiranih intervencija, } \\
\text { u smislu prakse jedna veličina odgovara svima (eng. one-size-fits-all), pri čemu se } \\
\text { propušta kritički uvažiti individualna obilježja i životne vrijednosti počinitelja. Funkcionira } \\
\text { u okviru uskog poimanja ljudske prirode i ignorira činjenicu da ljudi kao razvijena bića } \\
\text { teže ostvarivanju određenih individualnih životnih vrijednosti, kako bi živjeli smislene, } \\
\text { konstruktivne i sretne živote. }\end{array}$ \\
\hline Ignoriranje nekriminogenih potreba & $\begin{array}{l}\text { Ignorira se značaj nekriminogenih potreba kao što su primjerice određena osobna stanja } \\
\text { (tuga, zabrinutost) ili samopoštovanje. Nema prostora za poštivanje individualnosti i } \\
\text { konstruktivno pomaganje. }\end{array}$ \\
\hline Marginaliziranje motivacije počinitelja & $\begin{array}{l}\text { Motivacija počinitelja se razmatra tek minimalno. Teško je motivirati počinitelje da } \\
\text { se usmjere samo na redukciju recidivizma, to jest na kriminogene potrebe, pri čemu } \\
\text { ignoriranje njihovih ostalih potreba šteti odnosu počinitelja i službenika i na počinitelja } \\
\text { djeluje demotivirajuće. }\end{array}$ \\
\hline $\begin{array}{l}\text { Ignoriranje odnosa službenika i } \\
\text { počinitelja }\end{array}$ & $\begin{array}{l}\text { Ne uvažava se dovoljno odnos počinitelja i službenika, koji je postao površan, rutinski, } \\
\text { „šablonski“ i administrativan. Rad s počiniteljima sve više obilježava kompjuterizirani i } \\
\text { birokratski pristup. }\end{array}$ \\
\hline Naglasak na deficitima počinitelja & $\begin{array}{l}\text { Procjena i intervencije su usmjerene na deficite kod počinitelja, bez razmatranja njegovih } \\
\text { snaga i postignuća. }\end{array}$ \\
\hline
\end{tabular}

RPR modelu se naročito zamjera da je previše usmjeren na rizike i kriminogene potrebe, a premalo na zaštitne čimbenike i procese, snage, postignuća i aspiracije počinitelja (Canton, 2011, 93). Zaštitnim čimbenicima se smatraju obilježja osobe i njezinih okolnosti (životne situacije, obilježja okoline ili karakteristike osobe) koja smanjuju potencijalno štetan utjecaj rizičnih čimbenika i progrediranje kriminalnog ponašanja, odnosno čimbenici povezani sa smanjivanjem vjerojatnosti ponovnog počinjenja kaznenog djela (Ricijaš, 2009b; Vrselja, Sučić i Franc, 2009). Zaštitni čimbenici su do sada uglavnom istraživani na uzorcima maloljetnika i niskorizičnih počinitelja kaznenih djela, a daleko manje kod punoljetnih i visokorizičnih počinitelja (Mortimer, 2010). Lancaster i Lumb (2006) smatraju kako bilo koji pristup usmjeren samo na rizike ugrožava prava počinitelja, naročito onih procijenjenih visokorizičnima.

Na ove se kritike u literaturi odgovara usmjeravanjem prema sveobuhvatnijoj percepciji RPR modela i ukazivanjem na njegove prednosti, u smjeru prezentiranom Tabličnim prikazom 5. (Ward, Melser i Yates, 2007; Cullen, 2012; McNeill, 2012; Bourgon i Bonta, 2014; Melton i sur., 2014).

Tablica 5 Prednosti Modela rizik-potreba-responzivnost - odgovori na kritike (Ward, Melser $i$ Yates, 2007; Cullen, 2012; McNeill, 2012; Bourgon i Bonta, 2014; Melton i sur., 2014)

\begin{tabular}{|l|l|}
\hline \multicolumn{2}{|c|}{ PREDNOSTI MODELA RIZIK-POTREBA-RESPONZIVNOST - ODGOVORI NA KRITIKE } \\
\hline Etiološka komponenta & $\begin{array}{l}\text { Etiološka komponenta modela jasno naglašava potrebu razmatranja cjelokupne osobne situacije } \\
\text { počinitelja i njegove socijalne mreže u formuliranju objašnjenja njegovog kriminalnog ponašanja. } \\
\text { Primjedbe da model ignorira kontekstualne/ekološke čimbenike u rehabilitaciji počinitelja posljedica } \\
\text { su početne implementacije modela na relativno mehanički način, jer su se praktičari primarno } \\
\text { usmjerili samo na načela rizika, potreba i responzivnosti. }\end{array}$ \\
\hline $\begin{array}{l}\text { Snažna empirijska } \\
\text { utemeljenost modela }\end{array}$ & $\begin{array}{l}\text { Strategije procjene i tretmana su pažljivo evaluirane i provjeravane kako bi se dokazala njihova } \\
\text { valjanost i pouzdanost - praćenje načela ovog modela dokazano dovodi do smanjenja recidivizma. } \\
\text { Radi se o čvrstom rehabilitacijskom modelu koji dubinski objašnjava zašto programi funkcioniraju, s } \\
\text { obzirom da je model izveden iz teorije socijalnog učenja koja je snažno empirijski potkrijepljena. }\end{array}$ \\
\hline Praktična vrijednost modela & $\begin{array}{l}\text { Model ima praktičnu vrijednost, ne samo za osmišljavanje novih intervencija, već i za razvoj } \\
\text { instrumenata procjene kriminogenog rizika koji su se razvili korištenjem ovog pristupa i teorijskog } \\
\text { okvira. Radi se o instrumentima kod kojih se procjena temelji na velikom broju ranije provedenih } \\
\text { znanstvenih istraživanja to jest o aktuarskim instrumentima. }\end{array}$ \\
\hline
\end{tabular}


Snježana Maloić: Dominantna načela i modeli tretmanskog rada s punoljetnim počiniteljima kaznenih djela...

\begin{tabular}{|l|l|}
\hline Individualizirani pristup & $\begin{array}{l}\text { Već prva verzija modela uključila je pitanje motivacije u načelo responzivnosti. Usmjerenost na snage } \\
\text { nije proturječna s krajnjim ciljevima ovog modela, koji omogućava prihvaćanje interesa i postignuća } \\
\text { počinitelja. Model se specifično ne bavi nekriminogenim potrebama, no kroz primjenu načela } \\
\text { responzivnosti postoji prostor da se praktičar bavi i ovim potrebama, u slučaju da to može imati } \\
\text { učinak na ishod intervencije. }\end{array}$ \\
\hline Financijska isplativost & Intervencije utemeljene na ovom modelu su financijski isplative (eng. cost-effective). \\
\hline
\end{tabular}

Cullen (2012) posebno zamjera pokušaje poistovjećivanja RPR modela s pristupima usmjerenima isključivo na upravljanje rizikom. Ističe da ovaj model nije dio pokreta nove penologije, $s$ težnjom tretiranja počinitelja kao objekta kojim treba upravljati u smislu birokratske učinkovitosti i sigurnosti zajednice. Pojašnjava da se radi o tretmanskom modelu, čiji je zadatak tretiranje počinitelja kaznenih djela na etički i učinkovit način. Nadalje, ističe da se RPR model nikako i nikada ne smije sagledavati samo u svjetlu njegova tri temeljna načela, uz zanemarivanje njegovih ostalih načela i komponenti, to jest njegove složenosti. U tom smjeru njegova je preporuka da se umjesto o modelu započne govoriti o kanadskoj tretmanskoj paradigmi.

Taxman (2014) ukazuje da su se implementacijom RPR modela posljednjih desetljeća (čemu su zasigurno doprinijele i kritike) razvijala i njegova načela, kako bi se pomoglo što učinkovitije prevesti teoriju u praksu. Paralelno s rezultatima istraživanja učinkovitosti ovog modela, do sada je razvijeno više ključnih načela prezentiranih u Tabličnom prikazu 6. (Latessa, 2006; Ricijaš, 2009a; James, Eisen i Subramanian, 2012; Bonta i Andrews, 2012).

Tablica 6 Suvremena načela Modela rizik-potreba-responzivnost (Latessa, 2006; Ricijaš, 2009a; James, Eisen i Subramanian, 2012; Bonta i Andrews, 2012)

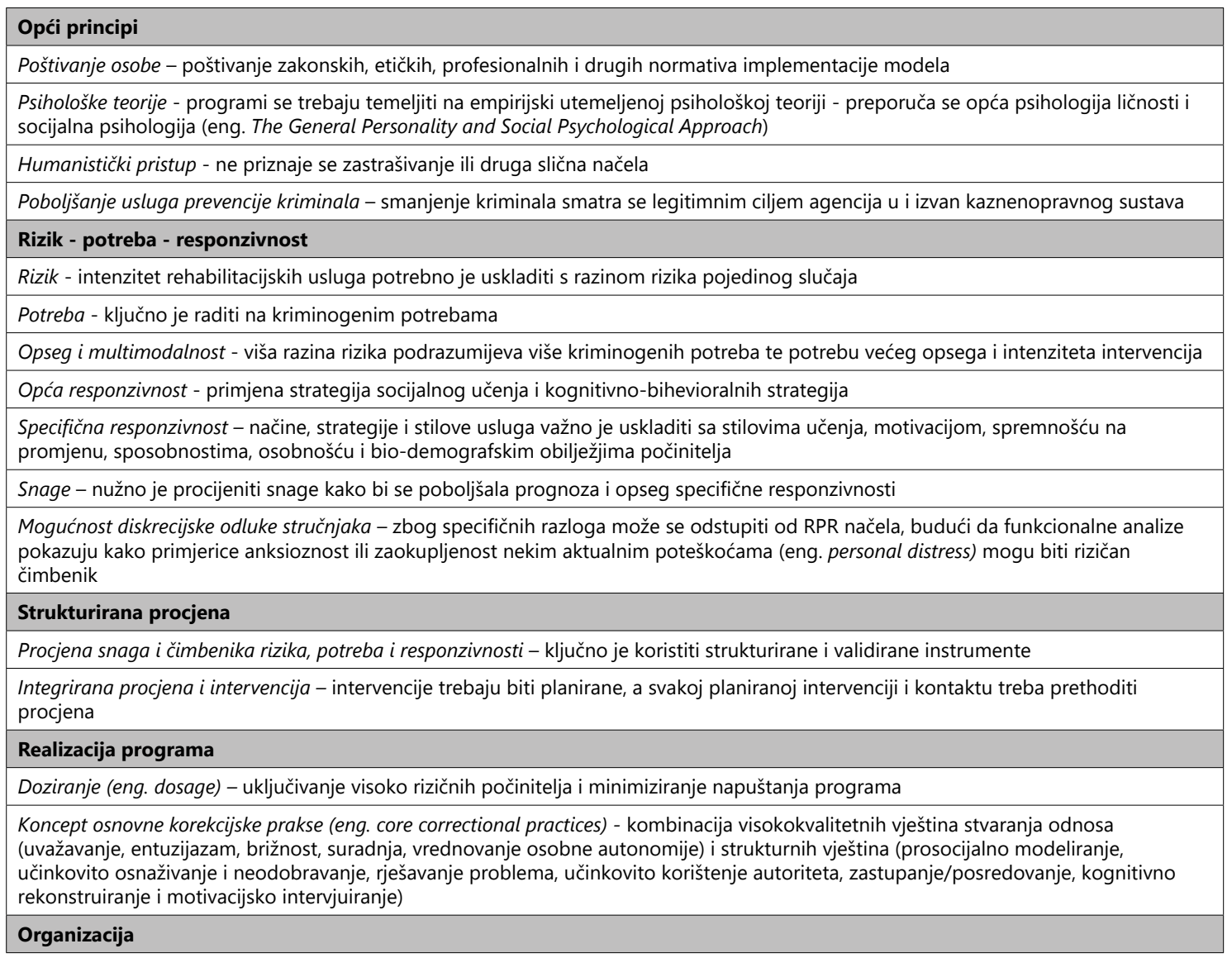


Baziranost na zajednici - preferira se okruženje u zajednici, međutim RPR načela se mogu koristiti i u institucionalnim uvjetima

Upravljanje - unaprjeđivanje selekcije, obrazovanja i kliničke supervizije osoblja, uz praćenje, povratnu informaciju i sustav

prilagođavanja; građenje podržavajućih organizacijskih sustava i kulture usmjerenih na učinkovitu praksu i kontinuitet pružanja usluga

Imajući u vidu negativne posljedice smjera Ništa ne funkcionira, kada je potencijalna učinkovitost rehabilitacijskog pristupa ozbiljno dovedena u pitanje, Cullen (2012) poziva na oprez u prihvaćanju eventualnih novih modela, bez čvrstih empirijskih dokaza njihove učinkovitosti u reduciranju recidivizma. Sugerira kako bi u tom smjeru ipak trebalo promišljati o mogućnostima poboljšanja ovog postojećeg, dokazano učinkovitog modela, naročito njegove primjene u praksi. Iz dostupne literature možemo vidjeti da se kod RPR modela najčešće naglašava potreba daljnjeg razvoja i učinkovitije primjene načela responzivnosti, pri čemu se ukazuje na nedorečenost ovog načela i na poteškoće njegove primjene u praksi (Bourgon i Bonta, 2014; Cohen i Whetzel, 2014; Melton i sur., 2014; Taxman, 2014).

\section{Načelo responzivnosti i izazovi koje donosi}

U stranoj se literaturi ističe da je načelo responzivnosti, unatoč svojoj središnjoj ulozi u pogledu humanosti i učinkovitosti RPR modela, nedovoljno artikulirano i teorijski nesofisticirano, a što ga čini posebno ranjivim za pojednostavljivanje i pogrešno interpretiranje u praksi (McNeill, 2012). Naglašava se kako su intervencije obično usmjerene na načela rizika i potreba kao primarnih ciljeva programiranja, a da uobičajena implementacija ovog modela zapravo ignorira svoje vlastito načelo, ili se u najmanju ruku teško nosi s idiosinkratičnim značajkama počinitelja (Ward, Melser i Yates, 2007; Taxman, 2014). Nadalje, Bourgon i Bonta (2014) konstatiraju da se načelo responzivnosti, kada se i pokušava primijeniti, svodi samo na razmatranje obilježja počinitelja, a bez razmatranja okruženja u kojem se tretmanski rad odvija (kao što su primjerice obilježja i vještine pomagača).

Evidentno je da je obim literature o responzivnosti daleko manji u odnosu na literaturu kojom se analiziraju načela rizika i potreba (Taxman, 2014). Istraživanja ovog načela su općenito zanemarena, a posebno je malo istraživanja o responzivnosti provedeno na uzorcima punoljetnih počinitelja kaznenih djela prema kojima se izvršavaju probacijske mjere i sankcije (Delaney i Weir, 2004; Bourgon i Bonta, 2014; Cohen i Whetzel, 2014). Bourgon i Bonta (2014) navode dva najvjerojatnija razloga za ovakvu situaciju:

1) istraživanje načela rizika i načela potreba je daleko jednostavnije,

2) nedovoljno definiranje responzivnosti u izvornom konceptu koji su ponudili Andrews, Bonta i Hoge 1990. godine - naglasak je u početku bio na kriminogenom riziku i kriminogenim potrebama, dok su čimbenici odgovora počinitelja na tretmansku intervenciju u okviru modela razvijani tek kasnije.

Ovo su ujedno i mogući razlozi zašto su u praksi manje implementirani procesi i strategije temeljene na responzivnosti (Lowenkamp i sur., 2012). To je svakako problematično, ako se primjerice uzme u obzir da zanemareni čimbenici responzivnosti mogu dovesti do odustajanja počinitelja od intervencije, kada se ostaje i bez željenih učinaka na dinamičke čimbenike rizika (Cohen i Whetzel, 2014). 
Promatrajući nastanak i razvoj ovog načela možemo vidjeti da su, u začecima razvoja RPR modela, njegovi autori najprije govorili o responzivnosti samo u smislu individualiziranog usklađivanja stilova i modaliteta intervencije sa stilovima učenja i sposobnostima počinitelja. Razlika između opće i specifične responzivnosti napravljena je tek kasnije (Andrews i sur., 1990, Bonta i Andrews, 2011, sve prema Cullen, 2012), dok se o sustavnoj (eng. systemic) responzivnosti govori tek unatrag nekoliko godina (Taxman, 2014). Tri glavne komponente responzivnosti prikazane su Slikom 2. (Mikšaj-Todorović, Buđanovac i Brgles, 1998; Clark, 2005; Ricijaš, 2006; Cullen, 2012; Ugwudike i Raynor, 2013; Ricijaš i sur., 2014; Taxman, 2014; Bourgon i Bonta, 2014).

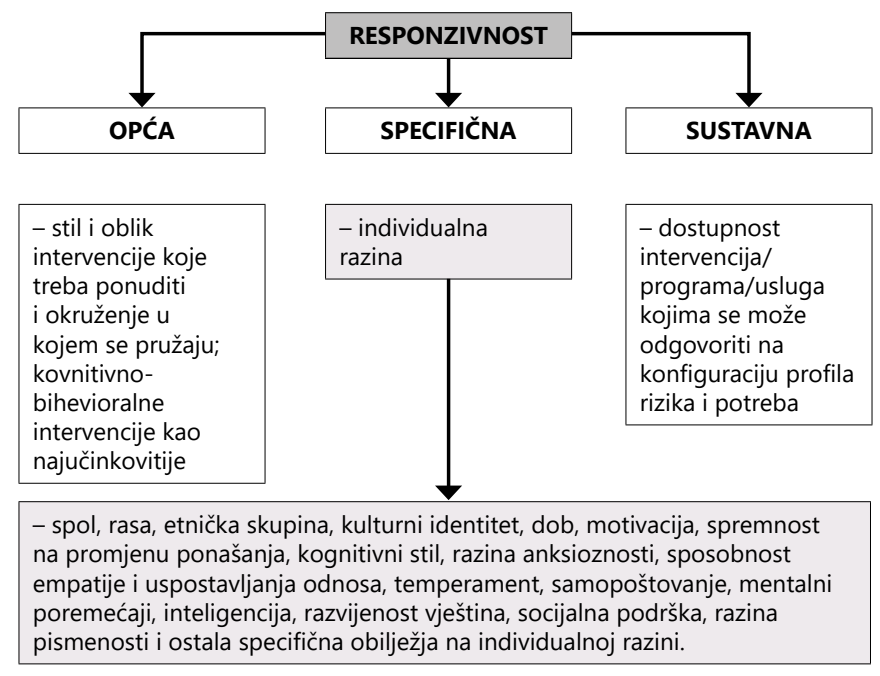

Slika 2 Shematski prikaz glavnih komponenti responzivnosti (Mikšaj-Todorović, Buđanovac i Brgles, 1998; Clark, 2005; Ricijaš, 2006; Cullen, 2012; Ugwudike i Raynor, 2013; Ricijaš i sur., 2014; Taxman, 2014; Bourgon i Bonta, 2014)

Kroz istraživanja opće responzivnosti kao najučinkovitije su prepoznate kognitivno-bihevioralne intervencije, utemeljene na modelu socijalnog učenja (Mikšaj-Todorović, Buđanovac i Brgles, 1998; Bourgon i Bonta, 2014). Ipak, kod kognitivno-bihevioralnog pristupa problematičnim se smatraju dvije polazišne pretpostavke (Lancaster i Lumb, 2006; Hussey, 2012, prema Ricijaš i sur., 2014):

1. pretpostavlja se aktivni angažman klijenta,

2. tendencija da se počinitelje percipira kao racionalne aktere, koji donose svjesne odluke i razumiju posljedice tih odluka.

Na ove kritike Cullen (2012) odgovara da se RPR model nikako ne može svesti samo na pojednostavljeno prihvaćanje kognitivno-bihevioralnih programa. Potvrđuje da se ovim modelom zastupa kognitivno-bihevioralni pristup, ali samo kao dio koherentne, višeslojne paradigme utemeljene na cijelom setu načela učinkovitog tretmana.

Specifična se responzivnost za istraživače i praktičare pokazala vrlo zahtjevnom, budući se odnosi na individualnu razinu. Bourgon i Bonta (2014) ističu kako je provedeno relativno malo istraživanja usmjerenih na diferencijalne učinke tretmana s obzirom na različita psiho-biološko-socijalna obilježja klijenata, a odnosila su se uglavnom na spol, nacionalnost/etničku pripadnost i rasu. Nije ih bilo ili su manje poznata istraživanja koja bi se primjerice bavila poteškoćama upućivanja u 
postojeće programe počinitelja niže inteligencije, anksioznih, s ograničenjima u čitanju, pisanju ili govoru (Andrews i Bonta, 2010, prema Cohen i Whetzel, 2014).

Istraživanja vezano uz spol postoje, ali se i nadalje ocjenjuju nedostatnima (Šućur i Žakman, Ban, 2005; Mcllwaine, 2011; O'Neill, 2011; Kelly i Bogue, 2014). lako su žene konstantno u populaciji koja čini kaznena djela zastupljene u relativno malom postotku, Kelly i Bogue (2014) ukazuju na zamjetan porast žena u kaznenopravnim sustavima na svjetskoj razini. Isti autori naglašavaju da je u Sjevernoj Irskoj broj žena kojima je izrečena zatvorska kazna od 2001. do 2010. godine porastao za $84,29 \%$. Navedeno je izazvalo zabrinutost zbog postojećih načina procjene rizika i odabira intervencija, koji su razvijani prvenstveno temeljem istraživanja na uzorcima muških počinitelja kaznenih djela i moguće nisu sasvim primjenjivi na ženskoj populaciji. Naime, poznato je da su putovi uključivanja žena u kriminal drugačiji nego kod muškaraca, pri čemu je posebno potrebno uzeti u obzir psihološke posljedice kod žena, kao što su osjećaji neadekvatnosti i srama, socijalna izolacija i siromaštvo, te manjak samopoštovanja i samopouzdanja (Mcllwaine, 2011; O'Neill, 2011). Kelly i Bogue (2014) smatraju da bi kod osmišljavanja programa za počiniteljice kaznenih djela trebalo dodatno istražiti i inkorporirati rodno-specifične čimbenike kao što su viktimizacija, odnosi, roditeljski stres, samopouzdanje i mentalno zdravlje. Napominju kako bi tek trebalo istražiti povezanost ovih čimbenika s recidivizmom, no da se u najmanju ruku radi o važnim čimbenicima responzivnosti. Naime, poboljšanjem njihovog emocionalnog stanja počiniteljice se osnažuje i za postizanje pozitivnih promjena kod drugih rodno neutralnih kriminogenih potreba.

Kao primjer vezano uz etničku pripadnost, odnosno kulturalni identitet, ovdje ćemo spomenuti rezultate istraživanja provedenog na uzorku Indijanaca u Americi. Melton i sur. (2014) u analizi rezultata ističu nekoliko specifičnih čimbenika responzivnosti, kao što su duhovna uvjerenja, manjak povjerenja prema državnim institucijama i povijesna trauma, temeljem čega se ističe potreba razvoja aktuarskih instrumenata validiranih i normiranih za specifične skupine počinitelja kaznenih djela u tom smislu. Cohen i Whetzel (2014) napominju kako razlike u etničkoj ili kulturalnoj pozadini između počinitelja i probacijskog službenika također mogu predstavljati problem.

Istraživanje koje su Cohen i Whetzel (2014) proveli u Sjedinjenim Američkim Državama, tijekom 2013./2014. godine, na uzorku od 20000 počinitelja kaznenih djela, dovelo je do spoznaje da probacijski službenici u određenim područjima više pažnje posvećuju čimbenicima responzivnosti nego u drugim regijama, kao i da ne prepoznaju razliku između kriminogenih potreba i čimbenika responzivnosti. Kroz analizu rezultata ovog istraživanja, autori ističu i niz dodatnih čimbenika responzivnosti koje bi bilo potrebno uzeti u obzir, kao što su imigracijski status, nedostatak osobnih dokumenata, nemogućnost prijevoza, kulturalne barijere, problemi s jezikom, otežano čitanje i pisanje, povijest zlostavljanja kod počinitelja. Istraživanje provedeno u Sjevernoj Irskoj je pokazalo da $37 \%$ osoba koje supervizira probacijska služba ima posebne potrebe, pri čemu prednjači mentalno zdravlje, dok je prosječni postotak u općem stanovništvu daleko manji i kreće se od 18 do 20\% (Mcllwaine, 2011).

U novijoj se literaturi kao značajni čimbenici responzivosti sve češće ističu čimbenici psihosocijalnog funkcioniranja počinitelja. Radi se o čimbenicima koji imaju učinak na izbore i odluke na dnevnoj razini, kao što su mentalno zdravlje, stabilnost stanovanja, ekonomska depriviranost, manjak hrane, financijskih sredstava ili prijevoza (Taxman, 2014; Cohen i Whetzel, 2014). Hipp i sur. 
(2010, prema Taxman, 2014) su primjerice utvrdili da je kod uvjetno otpuštenih osuđenika koji žive do $3 \mathrm{~km}$ od agencije koja pruža tretman vjerojatnost recidiva manje vjerojatna, nego kod onih koji žive dalje i tretman im je time teže dostupan. $U$ tom smislu, uz opću i pojedinačnu responzivnost, razvija se i nova, treća komponenta responzivnosti, koja u obzir uzima i specifične čimbenike psihosocijalnog funkcioniranja pojedinca te mogućnosti sustava koji pruža tretmanske intervencije da uvaži te čimbenike. Primjerice, ako se pružatelj tretmanske intervencije nalazi daleko od počinitelja kojima je ona potrebna, govorimo zapravo o problemu pristupa počinitelja toj intervenciji.

Taxman (2014) posebno naglašava upravo tu treću komponentu responzivnosti - sustavnu, kojom se podrazumijeva dostupnost intervencija (na razini jurisdikcija, institucija ili organizacija) potrebnih za adekvatan odgovor na konfiguraciju profila rizika i potreba populacije počinitelja kaznenih djela. Isti autor opisuje četiri glavna segmenta sustavne responzivnosti:

1. postojanje dovoljnog broja različitih programa dostupnih u zajednici i tijekom izvršavanja kazne zatvora (stopa raspoloživosti)

2. dovoljan postotak počinitelja koji mogu sudjelovati u intervencijama (stopa participacije)

3. dovoljan postotak počinitelja koji imaju pristup programima (stopa pristupa)

4. ponuđeni programi trebaju biti konzistentni s profilom rizika, potreba i specifičnom responzivnošću kako bi se osigurao učinak na recidivizam (stopa responzivnosti).

U znanstvenoj i stručnoj literaturi sve se češće naglašava kako nije dovoljno samo postaviti pitanje Što funkcionira?, već da se istraživači trebaju zapitati Što funkcionira za koga? (eng. What works for whom?) i potom u potragu za ovim odgovorima usmjeriti svoja istraživanja (Taxman, Thanner i Weisburd, 2006; Taxman, 2014). Autori koji upućuju kritike RPR modelu, kao i autori koji zastupaju njegove vrijednosti i učinkovitost, slažu se kako postoji prostor za daljnja poboljšanja ovog modela, naročito kod načela responzivnosti. Pri tome postoje različita razmišljanja kako bi se to moglo postići - daljnjim razvojem ovog modela ili kroz dijalog s drugim rehabilitacijskim modelima, pri čemu se najčešće spominje MKŽ (Ward, Melser i Yates, 2007; McNeill, 2009).

\section{Model kvalitetnih života kao alternativa modelu rizik-potreba-responzivnost ili signal za njegovo poboljšanje}

Razlike između RPR modela i MKŽ-a bazično proizlaze iz različitih paradigmi kroz koje se ovi modeli razvijaju. Dok je u središtu paradigme Što funkcionira? intervencija koja treba dovesti do promjene, paradigma prestanka i odvraćanja od činjenja kaznenih djela u središte stavlja počinitelja. Između ostalih, polazi se od pitanja zašto neki počinitelji nastavljaju činiti kaznena djela, dok drugi prestanu, čak i kada se prema njima primjenjuju iste intervencije. Ovom se paradigmom poseban naglasak stavlja na proces promjene, pri čemu se ističe kako taj proces uključuje kontinuirano donošenje odluka na individualnoj razini, te da je stoga nužno uvažiti percepciju samog počinitelja o njegovim vlastitim poteškoćama i potrebama (Friestad i Skog Hansen, 2010; Shapland i sur., 2012; Ward, 2012; Maloić, Mažar i Jandrić Nišević, 2013).

Jedna od prvih studija vezano uz paradigmu prestanka i odvraćanja od činjenja kaznenih djela je Leibrichova (1998, prema Shapland i sur., 2012). Provedena je u Novom Zelandu i obuhvatila 
je intenzivne razgovore s 48 počinitelja prema kojima su se 1987. godine obavljali probacijski poslovi, a koji nisu bili ponovo osuđeni do 1990. godine. Rezultati su bili zanimljivi, ali i zabrinjavajući. Naime, tek je nekoliko osoba spontano spomenulo probacijsku službu kao čimbenika u njihovom procesu prestanka činjenja kaznenih djela, a samo je polovica konstatirala da im je probacijska služba bila od koristi u tom procesu. Nadalje, izjave počinitelja koji su rad probacijske službe ocijenili osobno korisnim, ukazivale su na poseban značaj kvalitete uspostavljenog odnosa probacijskog službenika i počinitelja.

Kasnija istraživanja u okviru ove paradigme (McNeill, 2006; Shapland i sur., 2012), utvrdila su posebno važnu ulogu:

- odnosa počinitelja i službenika, ali i odnosa između počinitelja i osoba koje su mu važne,

- buđenja, razvoja i održavanja motivacije, ali i nade,

- aktivne participacije počinitelja u programiranju i provođenju intervencija,

- jačanja socijalne mreže i socijalnog kapitala počinitelja.

ŽKM predstavlja relativno nedavnu pojavu na rehabilitacijskom području (McNeill i Weaver, 2010). lako se u literaturi pojavljuje prije desetak godina, s primjenom je započeto nešto kasnije (Purvis, Ward i Willis, 2011; Prescott, 2013). Počiva na pretpostavkama da se kazneno djelo događa zbog poteškoća u načinima kako osoba nastoji ostvariti osnovne vrijednosti (eng. human goods), a koja se primjerice odnose na osjećaj sreće, interpersonalne odnose, iskustvo uspjeha na poslu i aktivnosti slobodnog vremena. Ovim se modelom kriminogene potrebe definiraju kao prepreke koje blokiraju ili ometaju prosocijalno ostvarivanje osnovnih vrijednosti (McNeill i Weaver, 2010). Neke su od osnovnih značajki ovog modela prezentirane Tabličnim prikazom 7. (Purvis, Ward $i$ Willis, 2011; Prescott, 2013; Willis i sur., 2013; Ward i Fortune, 2013).

Tablica 7 Osnovne značajke Modela kvalitetnih života (Purvis, Ward i Willis, 2011; Prescott, 2013; Willis i sur., 2013; Ward i Fortune, 2013)

\begin{tabular}{|l|l|}
\hline \multicolumn{2}{|c|}{ OSNOVNE ZNAČAJKE MODELA KVALITETNIH ŽIVOTA } \\
\hline Motivacija počinitelja & $\begin{array}{l}\text { Suradnja počinitelja i njegova spremnost za promjenu smatraju se ključnom za učinkovitost } \\
\text { bilo koje intervencije. }\end{array}$ \\
\hline $\begin{array}{l}\text { Usmjerenost na počinitelja i njegove } \\
\text { snage }\end{array}$ & $\begin{array}{l}\text { Naglasak je na počinitelju, a tek posredno na intervenciji. Nužno je uvažiti snage, specifične } \\
\text { interese, sposobnosti i težnje pojedinca, a ne se usmjeriti samo na postojeće deficite } \\
\text { (kriminogene potrebe). }\end{array}$ \\
\hline Osnovne vrijednosti & $\begin{array}{l}\text { Korekcijski programi trebaju biti usmjereni na povećanje svjesnosti počinitelja o njegovim } \\
\text { osnovnim vrijednostima i na pomaganje počinitelju da prevede te vrijednosti u konkretne } \\
\text { planove i ponašanja. }\end{array}$ \\
\hline Razvoj smislenog životnog plana & $\begin{array}{l}\text { Uz uvažavanje načela rizika, potreba i responzivnosti, počinitelju je potrebno pomoći u } \\
\text { razvijanju za njega smislenog životnog plana, nespojivog s mogućnošću daljnjeg činjenja } \\
\text { kaznenih djela. }\end{array}$ \\
\hline $\begin{array}{l}\text { Promoviranje osnovnih vrijednosti i } \\
\text { osobno važnih ciljeva }\end{array}$ & $\begin{array}{l}\text { Potrebno je definirati ciljeve na kojima osoba može i želi raditi, umjesto ciljeva izbjegavanja } \\
\text { na koje se nailazi u praksi (npr. cilj je stvoriti zadovoljavajuće i ispunjavajuće odnose, a ne } \\
\text { izbjegavati problematične odnose). }\end{array}$ \\
\hline Razvoj socijalnog kapitala & $\begin{array}{l}\text { Uz intervencije usmjerene na razvoj vještina upravljanja svojim životom tj. jačanja osobnog } \\
\text { kapitala, potrebno je jačati i kapacitete za promjenu u smislu jačanja socijalne mreže } \\
\text { počinitelja i općenito njegovih resursa u zajednici. }\end{array}$ \\
\hline
\end{tabular}

Ovim se modelom pridaje posebna pozornost osobnom identitetu, pri čemu se ističe da za učinkovitu intervenciju počinitelj mora željeti postići promjene u svojem životu, te da je prema 
tome najvažnija funkcija tretmana motivirati počinitelja ka težnji i vizualizaciji drugačije budućnosti (Ward, Melser i Yates, 2007; Cullen, 2012).

Preliminarna istraživanja sugeriraju da MKŽ može poboljšati učinkovitost intervencija koje se temelje na RPR modelu, naročito u dijelu povećanja angažmana počinitelja (Willis i sur., 2013). Postoje istraživanja koja su dokazala da se usmjeravanjem na ciljeve postignuća počinitelji lakše motiviraju i da je to učinkovito s terapijskog stajališta (Ward, Melser i Yates, 2007, Willis i sur., 2013). Već postoje i smjernice na koji način učinkovito integrirati MKŽ s RPR modelom i kognitivno-bihevioralnom terapijom u programe tretmana počinitelja seksualnih delikata (Ward, Mann i Gannon, 2007; Willis i sur., 2013). Ipak, aktualno se RPR model i MKŽ donekle doživljavaju kao dva natjecateljska, konkurentna modela (McNeill, 2012). lako se potvrđuju i njihova očigledna preklapanja, iz literature možemo uvidjeti i pojedine razlike, a koje proizlaze iz analiza ovih modela (Cullen, 2012; McNeill, 2012; Jandrić Nišević, 2014; Bougon i Bonta, 2014):

1.) RPR model svoje intervencije osmišljava na prediktorima kriminalnog ponašanja, dok se MKŽ prvenstveno oslanja na prediktore prestanka činjenja kaznenih djela.

2.) MKŽ fokus stavlja na motivaciju počinitelja i njegove snage, kao i na aktivnu ulogu počinitelja u osmišljavanju za njega smislenog i konstruktivnog životnog plana, u skladu s postojećim zakonskim normama. U okviru RPR modela, naglasak je više na čimbenicima rizika i kriminogenim potrebama te na potrebnim intervencijama kako bi se smanjio potencijalni rizik.

3.) RPR model se temeljno oslanja na aktuarsku procjenu, dok MKŽ daleko veći naglasak stavlja na kliničku sposobnost praktičara za razvoj individualiziranih intervencija sukladno specifičnostima pojedinog počinitelja.

Pri promišljanju ovih razlika svakako treba imati u vidu da ne postoji opće slaganje o tome da te razlike uistinu i postoje. Primjerice, iako se MKŽ dijelom promovira kao alternativa, a dijelom i kao moguće poboljšanje RPR modela, u svom radu Andrews, Bonta i Wormith (2011) zaključuju kako MKŽ zapravo malo toga može dodati RPR modelu. Uspoređujući suvremeni koncept RPR modela i aktualni koncept MKŽ-a, došli su do zaključka da prvi model može ponuditi sve što i drugi, a da pri tome ostaje čvrsto utemeljen na rezultatima istraživanja koji potvrđuju njegovu učinkovitost. Ipak, ovi autori potvrđuju i da se može učiti iz apela praktičara koje je MKŽ uvažio, stavljanjem naglaska na počinitelja i njegove snage. Smatraju da nije problem u samom RPR modelu i njegovim načelima, već u načinima primjene tih načela u praksi.

Ovdje je važno napomenuti i da se autori bliži MKŽ modelu često kritički osvrću na RPR model, istovremeno ističući prednosti MKŽ modela, kao i obrnuto - autori koji zastupaju načela RPR modela, ističu prednosti ovog modela i nedostatke MKŽ modela. Dojam je autorice kako zapravo nedostaje više radova u kojima bi autori radova pokušali pobliže sagledati potrebna poboljšanja upravo onog modela koji zastupaju, u smjeru njegovog daljnjeg empirijskog potvrđivanja, kao i u smjeru povećanja mogućnosti učinkovitije primjene tog modela u praksi. 


\section{Iskustva u primjeni suvremenih načela i modela u probacijskoj praksi}

Temeljem do sada provedenih istraživanja u okvirima RPR modela i MKŽ-a, možemo sumirati više načela važnih za učinkovit rehabilitacijski pristup počiniteljima kaznenih djela u zajednici (McNeill, 2006; Kovčo Vukadin, Rajić i Balenović, 2009; Crime and Justice Institute at Community Resources for Justice, 2009; Ricijaš, 2012; Shapland i sur., 2012; Mejovšek, 2013; Taxman, 2014; Maloić, Rajić i Mažar, 2015; Maloić, 2015):

- individualizirani pristup

- usmjerenost na čimbenike rizika i kriminogene potrebe,

- uvažavanje postignuća, snaga, interesa i pozitivnih aspiracija počinitelja,

- aktuarska procjena rizika, uz stručnu prosudbu,

- usklađivanje broja, vrste i intenziteta intervencija s procijenjenom razinom rizika,

- uvažavanje sve tri komponente načela responzivnosti,

- multimodalne intervencije uz procedure kojima se osigurava kontinuitet unutar i između programa ili drugih aktivnosti,

- realizacija intervencija u što otvorenijim uvjetima,

- izgradnja podržavajućeg profesionalnog odnosa, jačanje intrinzične motivacije i ostvarivanje konstruktivne suradnje s počiniteljem,

- kognitivno-bihevioralni pristup uz pozitivna potkrjepljenja prosocijalnog ponašanja,

- usvajanje i vježbanje novih vještina - jačanje osobnog kapitala,

- neposredna podrška u primarnoj zajednici - jačanje socijalnog kapitala,

- postojanje mjera kojima se osigurava da se programi/intervencije pružaju kako su i zamišljeni,

- mjerenje relevantnog procesa/prakse uz pružanje mjerljive povratne informacije,

- primjerena educiranost probacijskih službenika za procjenu i pružanje različitih oblika intervencija,

- razvoj organizacijskog konteksta i profesionalne kulture usmjerenih na učinkovito obavljanje probacijskih poslova i smanjenje recidivizma.

Pregledom sadržaja uvodno spomenutih Europskih probacijskih pravila, možemo vidjeti da su kroz ovaj svojevrsni vodič za učinkovit rad probacijskih službi uvaženi rezultati suvremenih istraživanja, odnosno spoznaje koje nude RPR model i MKŽ. Ovim se Pravilima ističe kako rad s počiniteljima treba biti usmjeren na rehabilitaciju i prestanak činjenja kaznenih djela. Naglašavaju se ljudska prava počinitelja i njegova dobrobit, potreba uspostavljanja pozitivnih odnosa probacijskih službenika i počinitelja, uvažavanja individualnih obilježja, okolnosti i potreba, pribavljanja 
informiranog pristanka počinitelja i ostvarivanja suradnje. Smatra se da procjena treba uključivati rizike, pozitivne čimbenike i potrebe, uz razmatranje responzivnosti počinitelja u odnosu na potrebne intervencije. Intencija je svakako u procjenu uključiti počinitelja, njegovu perspektivu i osobne aspiracije, kao i njegove snage i odgovornosti u smislu izbjegavanja daljnjeg činjenja kaznenih djela. Ističe se nužnost adekvatne educiranosti probacijskih službenika o koristima i ograničenjima aktuarskih instrumenata, kako bi navedeno mogli uključiti u svoju profesionalnu prosudbu.

No, u primjeni postojećih suvremenih načela i smjernica, probacijski se sustavi (ali i zatvorski) susreću s nizom problema, od koji se u kontekstu ovog rada važnim čini napomenuti sljedeće (Lancaster i Lumb, 2006; Purvis i Ward, 2011; Polaschek, 2012, prema Mejovšek, 2013; Bosker, Witteman i Hermans, 2013):

- U praksi se uočava pojava obrambenih (eng. defensive) procjena rizika od strane probacijskih službi, kada se veći broj počinitelja identificira visokorizičnima, kako bi se probacijski službenik i probacijska služba zaštitili od mogućih pogrešaka u procjeni i osude javnosti.

- Službenici nerijetko rade na velikom broju predmeta i glavni im je zadatak kontrola rizika to jest praćenje ponašanja počinitelja; zbog radne opterećenosti manje se mogu baviti počiniteljem na dubljoj, smislenijoj razini.

- Probacijski službenici nisu dovoljno educirani ili ne postoje dostatni organizacijski resursi za učinkovit rad s počiniteljima kaznenih djela. Primjerice, istraživanja pokazuju da se informacije dobivene kroz procjenu ne koriste uvijek i u intervencijskom planu, to jest da procijenjene kriminogene potrebe često nisu obuhvaćene ciljevima u intervencijskom planu, kao i da je korelacija između procijenjene razine rizika i intenziteta intervencija slaba.

- U praksi je evidentan manjak dovoljnog broja diferenciranih, dostupnih, jasno osmišljenih programa.

Kroz razvoj RPR modela i njegovih načela razvijen je cijeli niz instrumenata procjene počinitelja kaznenih djela (Bourgon i Bonta, 2014). Većina se suvremenih probacijskih službi koristi sustavom procjene temeljenom na analizi vjerojatnosti ponovnog počinjenja kaznenog djela, rizika nanošenja ozbiljne štete drugima ili sebi, te kriminogenih čimbenika na koje je moguće utjecati kako bi se umanjio rizik (Šimpraga i Vukota, 2010). Kako je polazišna točka hrvatske probacijske službe u tretmanskom radu s počiniteljima kaznenih djela procjena rizika i kriminogenih potreba, služba u tu svrhu od 2011. godine koristi aktuarski instrument procjene - Sustav procjene počinitelja (SPP) (Maloić i Mažar, 2014; Ministarstvo pravosuđa RH, 2015a). Ovaj je instrument osmišljen po uzoru na engleski aktuarski instrument Offender Assessment System-OASyS, koji se u engleskom zatvorskom i probacijskom sustavu koristi za procjenu rizika i kriminogenih potreba počinitelja, a prilagođen je i u drugim europskim zemljama (Lancaster i Lamb, 2006; Kovčo Vukadin, Rajić i Balenović, 2009; Canton, 2011; Maloić i Mažar, 2014; Šimpraga, Maloić i Ricijaš, 2014). Domaćem instrumentu tek predstoji validacija, a u njegovom daljnjem razvoju svakako bi trebalo uvažiti kritike koje se upućuju OASyS-u, ali i drugim aktuarskim instrumentima. 
Canton (2011) ističe kako je OASyS primarno fokusiran na rizik, dok je kroz instrument daleko marginalnije zastupljena responzivnost. Smatra da su kod načela responzivnosti počinitelj i probacijski službenik ostavljeni na modalitetu procjene osobe od strane osobe (eng. person-by-person judgment), koji se s druge strane RPR modelom smatra neadekvatnim za procjenu rizika. Aktuarskim instrumentima se zasad općenito zamjera nedovoljno uvažavanje načela responzivnosti, pri čemu se naglašava da validacija instrumenata nerijetko u obzir uzima samo rizik i kriminogene potrebe (Kelly i Welsh, 2008). Nadalje, posebno se ukazuje na manjak instrumenata koji razlikuju muškarce i žene (Latessa i Allen, 2003). lako su žene u probacijskoj populaciji u našoj zemlji zastupljene u manjem postotku, u probacijskom radu je ipak potrebno uvažiti njihova specifična obilježja i potrebe. Analiziramo li probacijsku populaciju u Hrvatskoj u razdoblju od 2009. do 2014. godine (14.445 osoba), u obavljanje probacijskih poslova bilo je uključeno 7,4 \% žena (1105), od čega je $90 \%$ žena imalo izrečenu posebnu obvezu/sankciju u zajednici ili su bile na uvjetnom otpustu, dok je samo za $10 \%$ probacijska služba dostavljala izvješće sucu izvršenja ili kaznionici/zatvoru vezano uz donošenje određene odluke (Šimpraga, 2015). Imajući u vidu postojeća ograničenja aktuarskih instrumenata, pozitivnom možemo ocijeniti prednost koju pri zapošljavanju u probacijsku službu hrvatski zakonodavac daje socijalnim pedagozima, socijalnim radnicima i psiholozima. Naime, radi se o stručnjacima koji tijekom svojeg fakultetskog obrazovanja stječu znanja nužna za kvalitetnu stručnu prosudbu, koja im potom omogućava i donošenje kvalitetnih i objektivnih diskrecijskih odluka.

U pojedinim državama postoje akreditacijski procesi i sustavi s unaprijed određenim kriterijima koje programi u okviru prakse utemeljene na dokazima trebaju zadovoljiti. Engleska i neke druge probacijske službe imaju svoje vlastite grupne akreditirane programe namijenjene počiniteljima kaznenih djela (Knight, Kemshall i Dominey, 2007). U engleskoj praksi postoje primjeri koji ukazuju na moguće negativne posljedice neadekvatne primjene RPR modela i načela responzivnosti. Primjerice, engleska probacijska služba se 2004. godine našla pod pritiskom da do kraja godine u postojeće akreditirane programe uputi 60.000 počinitelja, a što je rezultiralo žurnim i neadekvatnim upućivanjem počinitelja i velikim osipanjem (Knight, Kemshall i Dominey, 2007). Odustajanje počinitelja nakon što su već uključeni u program ocjenjuje se vrlo opasnim, jer rezultati istraživanja ukazuju na veći kriminalni povrat kod onih koji su bili uključeni u programe i odustali, nego kod onih koji nikad nisu ni bili uključeni (McNeill i Weaver, 2010).

Hrvatska probacijska služba nema vlastitih akreditacijskih programa, tako da prilikom uključivanja počinitelja u programe ovisi o broju, vrsti i dostupnosti postojećih programa u zajednici. Poteškoće probacijske službe vezano uz sustavnu responzivnost naročito do izražaja dolaze od 2015. godine, od kada je službi u nadležnost dano i izvršavanje uvodno navedenih sigurnosnih mjera. Zamjećuje se da je primjerice ovisnike o drogama nešto lakše uključiti u programe u zajednici, s obzirom na raznolikost programa koji se u zajednici nude. Veći je problem u programe uključiti počinitelje obiteljskog nasilja, jer je aktualna ponuda ovakvih programa vrlo oskudna, naročito u manjim sredinama. Općenito su programi potrebni počiniteljima koncentrirani u većim gradovima, što ih čini teže dostupnima počiniteljima koji žive u manjim mjestima ili primjerice na otocima. Najveći problem probacijska služba ima s programima potrebnima počiniteljima seksualnih delikata, jer ovakvi programi u zajednici gotovo da i ne postoje. Navedeno stavlja veliku odgovornost 
na probacijske službenike, koji na različite načine, sukladno individualnoj stručnosti i vještinama kojima raspolažu, pokušavaju kompenzirati ovaj veliki problem u radu s počiniteljima u zajednici.

Unatoč činjenici da RPR model direktno ne naglašava kriminalno ponašanje, u praksi se pokazalo uputnim uzeti u obzir specifičnosti pojedinih kaznenih djela, kako bi se osiguralo odgovarajući tretman/kontrolu, sukladno rizicima i potrebama počinitelja (počinitelji seksualnih delikata, počinitelji nasilnih kaznenih djela, počinitelji obiteljskog nasilja, počinitelji kaznenih djela počinjenih u prometu i slično) (Taxman, 2014). No, sa stajališta responzivnosti posebno se ističe da se ni takve skupine ne smiju smatrati homogenima, neovisno o kriteriju temeljem kojeg su selektirane. Primjerice, počinitelje kaznenih djela ovisne o drogama ne smije se percipirati kao homogenu grupu koja će pozitivno i simultano reagirati na jedan program koji bi trebao odgovarati svima, već je program nužno prilagoditi jedinstvenom tempu i odgovoru pojedinca na intervenciju (Delaney i Weir, 2004). Naime, ranije se s počiniteljima kaznenih djela radilo samo temeljem istog seta kriminogenih potreba, uz pogrešnu pretpostavku da svi trebaju istu intervenciju (Lowenkamp i sur., 2012). Nisu se dovoljno uzimale u obzir različite prepreke adekvatnom odgovoru na tretman kod ovisnika o drogama, kao što su kognitivni i intelektualni deficiti, oskudne socijalne vještine i (ne) spremnost na promjenu, što znači da su ponuđeni programi bili daleko iznad sposobnosti pojedinih počinitelja u tom vremenu (Delaney i Weir, 2004).

Za probacijske službe posebno je važno pitanje motiviranosti počinitelja i njegove spremnosti za promjenu. Lancaster i Lumb (2006) ističu da informacije o ranijem kriminalnom ponašanju i ranijem kažnjavanju počinitelja sudjeluju u 1/3 ponderiranih bodova u OASyS-u, dok se od više od sto pitanja samo jedno odnosi na motivaciju počinitelja. Detaljnije se ne analizira što motivira počinitelja niti do koje mjere i kako bi se motivacija mogla povećati. Manjak strukture za procjenu motivacije kod procjene rizika ovi autori smatraju vrlo problematičnim, budući da cjelokupna procjena u konačnici određuje strukturu i sadržaj intervencija. Do sada je poznato da je motivacija ključna za prestanak činjenja kaznenih djela, vjerojatno više od detalja o ranijem ili sadašnjem ponašanju počinitelja (Court, 2004; Lancaster i Lumb, 2006). Stoga bi procjena počinitelja u svakom pojedinom slučaju trebala uključiti i analizu motivacije, razinu individualnog razvoja zrelosti (koja ne mora odgovarati pretpostavljenoj zrelosti za kronološku dob), te kognitivne otvorenosti i spremnosti za promjene (McNeill, 2010). Istraživanje koje su u Hrvatskoj proveli Sučić, Ricijaš i Glavak-Tkalić (2014) je pokazalo da su počinitelji s kojima radi probacijska služba često nedovoljno informirani o sankciji koja im je izrečena, te da je njihova motivacija za suradnju nerijetko samo formalna, kako bi izbjegli zatvorsku kaznu.

Spremnost za angažman u okviru tretmana (eng. treatment readiness) Ward i sur. (2004, prema Casey i sur., 2007) definiraju kao postojanje obilježja (stanja ili dispozicija) počinitelja ili terapijske situacije, za koje je vjerojatno da će pospješiti sudjelovanje počinitelja, a time i povećati učinkovitost terapijskog procesa. Pri tome, unutarnji čimbenici spremnosti za angažman uključuju stav o tretmanu, ranija iskustva s programima i ciljeve počinitelja, dok se vanjski odnose na mjeru u kojoj je tretman nametnut, okolnosti/okruženje u kojem se tretman provodi, te na dostupnost resursa za podršku provođenju programa. Kako je vanjske čimbenike teško mjeriti, a i mnogi su izvan kontrole onih koji program provode, zasad postoje pokušaji da se izmjere unutarnji aspekti spremnosti, kroz razvoj i validaciju posebnih instrumenata procjene. Paralelno s ovim pokušajima, u praksi se sve više primjenjuju i tehnike usmjerene na povećanje motivacije počinitelja i njegove 
spremnosti za promjenu. Lancaster i Lumb (2006) ističu kako je engleska probacijska služba prihvatila suvremene tehnike kao što je krug promjene (eng. cycle of change), tehniku koju su 80-ih godina 20. stoljeća razvili Prochaska i DiClemente, kao i tehniku motivacijskog intervjuiranja. Ove se tehnike sada koriste u radu s počiniteljima kaznenih djela unatoč tome što motivacija sama po sebi u procjeni rizika (ponderiranju) značajnije ne utječe na osmišljavanje intervencija (Delaney i Weir, 2004). O osnovama primjene ovih tehnika educirani su i hrvatski probacijski službenici kroz uvodno spomenuti EU projekt (Maloić i Mažar, 2014).

Sa sve većom prihvaćenošću RPR modela, a potom i dodatno pod utjecajem MKŽ-a, u praksi se sve veći naglasak stavlja na potrebne vještine praktičara (Bracken, 2014). Pod utjecajem MKŽ-a sve se veća pozornost pridaje i odnosu probacijskog službenika i počinitelja (Lancaster i Lumb, 2006). Naime, dokazana je povezanost zadovoljstva strukturom programa i dobivenom podrškom od strane osoblja sa smanjenjem povratništva u činjenju kaznenih djela (Maruna i Farrall, 2004, prema Wood, Kade i Sidhu, 2009). Temeljem niza objavljenih meta-analiza kroz literaturu o korekcijskom tretmanu razvijen je koncept tzv. osnovne korekcijske prakse (eng. core correctional practices), koji se danas promovira i kao sastavni dio primjene RPR modela (Bonta i Andrews, 2012).

Nakon analize niza istraživanja, Latessa i sur. (2013) konstatiraju kako dobra educiranost probacijskih službenika i korištenje osnovne korekcijske prakse dovode do značajnog smanjenja kriminalnog povrata. Nadalje, sve se češće ističe i pažnja koju je potrebno posvetiti organizacijskom kontekstu i profesionalnoj kulturi u okviru kojih se intervencije pružaju (McNeill i Weaver, 2010). Stoga je primjerice posebno potrebno voditi računa o radnom opterećenju probacijskih službenika (Matthews, 2009), naročito ako se, kao kod hrvatske probacijske službe, kontinuirano povećava broj predmeta. Također, nikako se ne bi smjela zanemariti kontinuirana izobrazba probacijskih službenika, koja se u mnogim zemljama ne provodi u mjeri, na načine i u opsegu potrebnom za učinkovit probacijski rad (Maloić i Ricijaš, 2014).

\section{Zaključak}

Važeći zakonski propisi stavljaju hrvatskoj probacijskoj službi u nadležnost velik broj probacijskih poslova. Dok se dio tih poslova odnosi na dostavu različitih informacija o počinitelju i specifičnim okolnostima u zajednici, izvršavanje probacijskih mjera i sankcija podrazumijeva i neposredan rad s počiniteljima kaznenih djela, dakle i određene oblike i intenzitet tretmanskog rada. Logično je da je mlada hrvatska probacijska služba u procesu osmišljavanja vlastitog rehabilitacijskog pristupa posegnula za spoznajama koje o učinkovitim načelima i modelima već postoje u svijetu. Prihvatila je RPR model koji je, unatoč postojećim kritikama i manjkavostima, općenito prihvaćen i ima zadovoljavajuću empirijsku potvrđenost svoje učinkovitosti.

Autorica ovog rada je svjesna kako je samo djelomično opravdano neposredno uspoređivati RPR i MKŽ model, s obzirom na njihovu različitu povijest nastajanja i svrhu. No, prikaz njihovih prednosti i kritika s druge strane dovodi do boljeg uočavanja potencijalnih koristi primjene pojedinog modela. Naime, RPR model prvenstveno nastoji odgovoriti na pitanja o uzročnim čimbenicima, razini kriminogenog rizika i planiranju intervencija, kako bi se znanstveno utemeljeno tretmanski djelovalo. S druge strane, MKŽ je više klinički model, nastao s ciljem usmjeravanja na pozitivnije 
aspekte psihosocijalnog funkcioniranja počinitelja, kako bi se fokus tretmana s rizika usmjerio na jake strane počinitelja.

lako RPR model donosi niz prednosti, svakako je potrebno imati u vidu i kritike i kontinuirane napore u smjeru poboljšanja primjene ovog modela u praksi. Posebno je u praksi potrebno paziti da se model provodi cjelovito, kako bi se izbjeglo pojednostavljivanje ili njegova parcijalna primjena. U pravu je Cullen (2012) kada ističe da se ne radi samo o tri načela, već o cjelovitoj tretmanskoj paradigmi. U primjeni ovog modela poseban je izazov načelo responzivnosti te usklađivanje tretmanskih metoda i tehnika s rizicima, potrebama i obilježjima responzivnosti kod osuđenika. Unatoč razvojnim pomacima u njegovoj konceptualizaciji, u praksi se i nadalje nailazi na niz nedoumica i zapreka. No, to nikako ne bi smjelo dovesti do ignoriranja ovog načela jer bi se u tom slučaju u pitanje dovela i potencijalna učinkovitost bilo koje intervencije. Financijska isplativost, koja se ističe kao važna prednost RPR modela, sigurno je ugrožena ako zbog nedovoljne primjene načela responzivnosti veći broj intervencija ostane bez učinka. Na taj način ugrožava se i sigurnost zajednice. Ovo je načelo nužno uvažiti, kako kod izrade i validacije instrumenata procjene, tako i prilikom programiranja rehabilitacijskih intervencija, a pri čemu nedvojbeno mogu pomoći daljnja istraživanja. Za pretpostaviti je da bi aktuarski pristup u skorijoj budućnosti mogao pružiti kvalitetnije rezultate i u segmentu responzivnosti, što potvrđuju i sami autori RPR modela, pozivajući na primjenu modela u cjelini i uvažavanje svih njegovih do sada razvijenih načela.

Edukacija probacijskih službenika je ključna, pa tako i o načelu responzivnosti, pri čemu im sustav mora osigurati i mogućnost primjene tog načela (Cohen i Whetzel, 2014). Probacijske službenike je potrebno educirati za primjenu aktuarskih instrumenata procjene, ali istovremeno moraju posjedovati i znanja i vještine potrebne za kliničku procjenu. Potrebno ih je osposobiti za primjenu profesionalne prosudbe u okviru pristupa utemeljenog na rezultatima istraživanja. Nadalje, nužno je osigurati dovoljan broj probacijskih službenika i raditi na povećanju lepeze programa dostupnih počiniteljima, kako bi se moglo uvažiti sve tri komponente responzivnosti.

Primjena rezultata istraživanja provedenih kroz razvoj paradigme prestanka i odvraćanja od činjenja kaznenih djela dokazano može pridonijeti učinkovitosti intervencija prema počiniteljima kaznenih djela. Na ovaj se način može smanjiti broj počinitelja koji se pod pritiskom sankcije uključuju u programe, a potom samo formalno sudjeluju ili odustaju. Model kvalitetnih života naglašava neke zaista bitne spoznaje za rad s počiniteljima kaznenih djela. Ovaj model na određeni način u središte probacijskog rada vraća samog počinitelja i njegov socijalni kontekst. Aktivna uloga počinitelja, jačanje motivacije za suradnju i spremnosti za promjenu, razvoj za njega smislenih ciljeva postignuća i smislenog životnog plana i jačanje osobnog, ali i socijalnog kapitala, ni na koji način nije u suprotnosti s kanadskom paradigmom.

Procjena bi stoga uz kriminogeni rizik i kriminogene potrebe uvijek trebala obuhvatiti i zaštitne čimbenike, snage, ali i cjelokupno psihosocijalno funkcioniranje (destabilizatore na dnevnoj razini), kako bi se osiguralo da se programiranjem obuhvati sve čimbenike koji mogu utjecati na proces promjene. Rehabilitacijske intervencije bez daljnjega trebaju biti usmjerene na upravljanje rizikom i zaštitu zajednice, ali da bi se dosegla njihova učinkovitost, počinitelji kaznenih djela ih moraju doživljavati smislenima i korisnima u svom individualnom kontekstu. 
Pri odabiru načina procjene i intervencija, nikako se ne smije zaboraviti nastale štete prouzročene velikim sumnjama u moguću učinkovitost rehabilitacijskog pristupa, nakon Martinsonovog Ništa ne funkcionira. Također se ne smije ignorirati sumnje u mogućnosti promjene počinitelja kaznenih djela koje se i danas nerijetko čuju u okviru penološkog populizma (Maloić, 2013). Važnim se stoga čini paziti na empirijsku potvrđenost intervencija koje se biraju u radu s počiniteljima kaznenih djela u zajednici. U tom smjeru nužno je slijediti načela učinkovitih korekcijskih intervencija, prvenstveno zbog njihove empirijske utemeljenosti.

Zaključno, iako se u ovom radu nije analizirao model restorativne pravde iz uvodno navedenih razloga, treba napomenuti da se radi o potencijalnom području daljnjeg razvoja probacijskog rada s punoljetnim počiniteljima kaznenih djela i u našoj zemlji. Stoga je i u tom smjeru nužno pratiti rezultate istraživanja i suvremene spoznaje $\mathrm{i}$ iskustva.

\section{Literatura}

Andrews, D. A., Bonta, J., Wormith, J. S. (2011): The Risk-Need-Responsivity (RNR) Model - Does Adding the Good Lives Model Contribute to Effective Crime Prevention?. Criminal Justice and Behavior. 38 (7). 735-755.

Bonta, J., Andrews, D. (2012): Viewing offender assessment and rehabilitation through the lens of the risk-need-responsitivity model. U: McNeill, F., Raynor, P., Trotter, C. (ur.), Offender Supervision: New directions in theory, research and practice. Abingdon. Routledge. 19-38.

Boone, M. (2016): Community punishment in the Netherlands. U: Robinson, G., McNeill, F. (ur.), Community punishment: European perspectives. Routledge. Abingdon. 95-113.

Bosker, J., Witteman, C., Hermanns, J. (2013): Do intervention plans meet criteria for effective practice to reduce recidivism? How probation officers forget about social capital and basic needs. European Journal of Probation. 5 (1). 65-85.

Bourgon, G., Bonta, J. (2014): Reconsidering the Responsivity Principle: A Way to Move Forward. Federal Probation. 78 (2). 3-10.

Bracken, D. C. (2014): Correctional officer training in Canada. U: Durnescu, I., McNeill, F. (ur.), Understanding Penal Practice. Routledge. Abingdon.

Canton, R. (2011): Probation: working with offenders. Routledge. Abingdon.

Casey, S., Day, A., Howells, K., Ward, T. (2007): Assessing Suitability for Offender Rehabilitation: Development and Validation of the Treatment Readiness Questionnaire. Criminal Justice and Behavior. 34 (11). 1427-1440.

Clark, M. D. (2005): Motivational Interviewing for Probation Staff: Increasing the Readiness to Change. Federal Probation. 69 (2). 22-28.

Cohen, T. C., Whetzel, J. (2014): The Neglected "R"—Responsivity and the Federal Offender. Federal Probation. 78 (2). 11-18

Court, D. (2004): Applying the Findings of the Liverpool Desistance Study in Probation Practice: Views from the Front-Line 2. Probation Journal. 51 (3). 237-240.

Crime and Justice Institute at Community Resources for Justice (2009): Implementing EvidenceBased Policy and Practice in Community Corrections. National Institute of Corrections. Washington, DC. 
Snježana Maloić: Dominantna načela i modeli tretmanskog rada s punoljetnim počiniteljima kaznenih djela...

Cullen, F. T. (2012): Taking rehabilitation seriously: Creativity, science, and the challenge of offender change. Punishment and Society. 14 (1). 94-114.

Delaney, P., Weir, M. (2004): Matching Offenders and Programmes: The Responsivity Principle at Work in the Cornmarket Project for Offenders, Substance Misusers and their Families in Wexford. Irish Probation Journal. 1 (1). 77-85.

Friestad, C., Skog Hansen, I. L. (2010): Gender Differences in Inmates Anticipated Desistance. European Journal of Criminology. 7 (4). 285-298.

James, J., Eisen, L. B., Subramanian, R. (2012): A View from the States: Evidence Based Public Safety Legislation, Journal of Criminal Low and Criminology, 102, 3, 821-849.

Jandrić Nišević, A. (2014): Novi trendovi u području penološke rehabilitacije i tretmana počinitelja kaznenih djela. 4. hrvatski kongres socijalnih pedagoga. Supetar.

Jelínek, M., Matoušková, A. (2015): In the name of the victim: Victim perspective in criminal proceedings with a focus on the post-sentence level. Ljetopis socijalnog rada. 22 (1). 139-154.

Kazneni zakon. Narodne novine, br. 125/11, 144/12, 56/15, 61/15.

Kelly, J., Bogue, J. (2014): Gender Differences in Criminogenic Needs among Irish Offenders. Irish Probation Journal. 11. 87-102.

Kelly, C. E., Welsh, W. N. (2008): The Predictive Validity of the Level of Service Inventory-Revised for Drug-Involved Offenders. Criminal Justice and Behavior. 35 (7). 819-831.

Knight, V., Kemshall, H. and Dominey, J. (2007): Gathering offender perceptions of probation programmes: Potential, pitfalls and limits. British Journal of Community Justice. 5 (1). 65-77.

Koller-Trbović, N., Nikolić, B., Ratkajec Gašević, G. (2010): Usporedba instrumenata za procjenu rizika i potreba djece i mladih. Kriminologija i socijalna integracija. 18 (2). 1- 14.

Kokić Puce, Z., Kovčo Vukadin, I. (2006): Izvršavanje alternativnih sankcija u Republici Hrvatskoj. Hrvatski ljetopis za kazneno pravo i praksu. 13 (2). 745-794.

Kovčo Vukadin, I., Maloić, S., Rajić, S. (2012): Policija i probacija - novi partneri u zaštiti zajednice?. Policija i sigurnost. 21 (4). 800-820.

Kovčo Vukadin, I., Rajić, S., Balenović, M. (2009): Uspostava probacijskog sustava - novi izazov za Hrvatsku? Hrvatski ljetopis za kazneno pravo i praksu. 16 (2). 711-751.

Kovčo Vukadin, I., Rajić, S., Maloić; S. (2011): Izazovi u izgradnji probacijskog sustava u Republici Hrvatskoj. Hrvatski ljetopis za kazneno pravo i praksu (Zagreb). 18 (2). 717-735.

Labrecque, R. M., Schweitzer, M., Smith, P. (2014). Exploring the perceptions of the offenderofficer relationship in a community supervision setting. Journal of International Criminal Justice Research. 1. 31-46.

Lancaster, E., Lumb, J. (2006): The Assessment of Risk in the National Probation Service of England and Wales. Journal of Social Work. 6 (3). 275-291.

Latessa, E. J. (2006): What Works in Reducing Recidivism?, University of St. Thomas Law Journal, $3,3,521-535$.

Latessa, J. E., Allen, H. E. (2003): Corrections in the Community. Anderson Publishing. Cincinnati. 
Latessa, J. E., Smith, P., Schweitzer, M., Labrecque, R., M. (2013): Evaluation of the Effective Practices in Community Supervision Model (EPICS) in Ohio. University of Cincinnati. Cincinnati.

Lowenkamp, C., Holsinger, A. M., Robinson, C. R., Cullen, F. T. (2012): When a Person Isn't a Data Point: Making Evidence-Based Practice Work. Federal Probation. 76 (3). 11-21.

Maloić, S. (2013): Suvremeni pristupi kažnjavanju kao determinante kvalitete života u obitelji, susjedstvu i zajednici - nove perspektive suzbijanja kriminala. Kriminologija i socijalna integracija. 21 (2). 31-44.

Maloić, S. (2015): Probacija prema punoljetnim počiniteljima kaznenih djela - pomoć ili nadzor? Kriminologija i socijalna integracija. 23 (1). 157-179.

Maloić, S., Mažar, A. (2014): Pristupi i tehnike rada s ovisnicima u probaciji. Kriminologija i socijalna integracija. 22 (1). 211-239.

Maloić, S., Mažar, A., Jandrić Nišević, A. (2013): Zlouporaba droga - pristupi, paradigme i načini rada u okviru probacije. Ljetopis socijalnog rada. 20 (3). 481 - 508.

Maloić, S., Rajić, S. (2012): Potreba i značaj razvoja suradnje probacijskog sustava i sustava socijalne skrbi u RH. Ljetopis socijalnog rada. 19 (1). 29-52.

Maloić, S., Rajić, S., Mažar., A. (2015): Značaj suradnje probacijskog i zatvorskog sustava u prevenciji kriminalnog povrata. Kriminologija i socijalna integracija. 23 (1). 129-156.

Maloić, S., Ricijaš, N. (2014): Kompetencije i profesionalni razvoj probacijskih službenika. Ljetopis socijalnog rada. 21 (3). 511-540.

Maloić, S., Šimpraga, D. (2014): Unaprjeđivanje kvalitete izvršavanja probacijskih poslova. Praktični menadžment. 5 (1). 127-134.

Matthews, J. (2009): People first: Probation officer perspectives on probation work - A practitioner's response. Probation Journal. 56 (1). 61-67.

Mcllwaine, P. (2011): Diversity Profile of Offenders under the Supervision of the Probation Board for Northern Ireland. Irish Probation Journal. 8. 82- 92.

McNeill, F. (2006): A desistance paradigm for offender management. Criminology and Criminal Justice. 6 (1). 39-26.

McNeill, F. (2009): What Works and What's Just? European Journal of Probation. 1 (1). 21 - 40.

McNeill, F. (2012): Four forms of 'offender' rehabilitation: Tos an interdisciplinary perspective. Legal and Criminological Psychology. 17 (1). 18-36.

McNeill, F., Weaver, B. (2010): Changing Lives? Desistance Research and Offender Management. McNeill, F., Weaver, B. (2010) Changing Lives? Desistance Research and Offender Management. SCCJR Project Report; No.03/2010.

Mejovšek, M. (2013): Evaluacija intervencijskih programa u penologiji. Kriminologija i socijalna integracija. 21 (1). 81-98.

Melton, A., Cobb, K., Lindsey, A., Colgan, R. B., Melton, D. J. (2014): Addressing Responsivity Issues with Criminal Justice-Involved Native Americans. Federal Probation. 78(2). 24-31.

Mikšaj-Todorović, Lj., Buđanovac, A., Brgles, Ž. (1998): Rehabilitacijski programi u institucijama u hrvatskoj penološkoj teoriji i praksi. Hrvatska revija za rehabilitacijska istraživanja. 34 (1). 83-92. 
Snježana Maloić: Dominantna načela i modeli tretmanskog rada s punoljetnim počiniteljima kaznenih djela...

Ministarstvo pravosuđa RH (2014): Izvješće o radu probacijske službe za 2014. godinu. https:// pravosudje.gov.hr/UserDocs/mages/dokumenti/Pravo\%20na\%20pristup\%20 informacijama/Izvje\%C5\%A7\%C4\%87e\%200\%20radu\%20probacijske\%20 slu\%C5\%BEbe\%20za\%202013.\%20godinu.pdf (Preuzeto 15.12.2015.)

Ministarstvo pravosuđa RH (2015a): Izvješće o radu probacijske službe za 2014. godinu. sa https://vlada.gov.hr/UserDocs/mages//Sjednice/2015/230\%20sjednica\%20 Vlade//230\%20-\%206.pdf.(Preuzeto 16.11.2015.)

Ministarstvo pravosuđa RH (2015b): Sustav procjene počinitelja - Priručnik. Interni materijal. Ministarstvo pravosuđa RH (2016): Izvješće o radu probacijske službe za 2015. godinu. U izradi.

Morgenstern, C., Larrauri, E. (2013): European Norms, Policy and Practice. U: McNeill, F., Beyens, K. (ur.), Offender Supervision in Europe. Palgrave Macmillan. Basngstoke. 125-154.

Mortimer, R. (2010): Risk factors for offending: A developmental approach. A thesis submitted to The University of Birmingham for the degree of Doctorate in Forensic Psychology Practice. Birmingham.

Nikolić, B., Koller-Trbović, N i Žižak, A. (2002): Metrijske karakteristike formulara za procjenu rizičnosti / potreba (FPRP). Hrvatska revija za rehabilitacijska istraživanja. 38 (1). 103-121.

O'Neill, J. (2011): The Inspire Women's Project: Managing women offenders within the community. Irish Probation Journal. 8. 93-108.

Prescott, D. S. (2013): The Good Lives Model (GLM) in Theory and Practice. Visiting expert's paper. 154th UNAFEl International Training Course "Stress Management of Correctional Personnel - Enhancing the Capacity of Mid-Level Staff". From 15 May to 28 June 2013. Tokyo.

Purvis, M., Ward, T., Willis, G. (2011): The Good Lives Model in Practice: Offence Pathways and Case Management. European Journal of Probation. 3 (2). 4-28.

Radetić-Paić, M. (2010): Specifični rizici i potrebe djece i mladeži s poremećajima u ponašanju grada Pule. Kriminologija i socijalna integracija. 18 (1). 13-23.

Rajić, S., Maloić, S., Knotek-Iveta, Ž. (2005): Izvršavanje uvjetne osude sa zaštitnim nadzorom i rad za opće dobro na slobodi - Alternativne sankcije u RH - stanje i perspektive. Kriminologija i socijalna integracija. 13 (1). 119-132.

Ricijaš, N. (2006): Instrumenti procjene djece i adolescenata - mogućnosti primjene kod probacije za maloljetnike. Ljetopis socijalnog rada. 13 (2). 271-295.

Ricijaš, N. (2009a): Atribuiranje vlastitog delinkventnog ponašanja nisko rizičnih i visoko rizičnih maloljetnih delinkvenata. Kriminologija i socijalna integracija. 17 (1). 13-26.

Ricijaš, N. (2009b): Pripisivanje uzročnosti vlastitog delinkventnog ponašanja mladih. Doktorska disertacija. Zagreb : Pravni fakultet. https://bib.irb.hr/datoteka/384000.DOKTORAT_ Neven_Ricijas.pdf (Preuzeto 17.11.2015.)

Ricijaš, N. (2012): Procjena, planiranje i izvještavanje u izvršavanju maloljetničkih alternativnih sankcija. Priručnik. Ministarstvo socijalne politike i mladih. Zagreb.

Ricijaš, N., Jeđud Borić, I., Lotar Rihtarić, M., Mirosavljević, A. (2014): Pojačana briga i nadzor iz perspektive mladih i voditelja mjere. Zagreb : Ured UNICEF-a za Hrvatsku.

Schwalbe, C. S. (2012): Toward an Integrated Theory of Probation. Criminal Justice and Behavior. 39 (2). 185-201. 
Shapland, J., Bottoms, A., Farrall, S., McNeill, F., Priede, C., Robinsin, G. (2012): The quality of probation supervision - a literature review. Centre for Criminological Research, University of Sheffield and University of Glasgow.

Sučić, I., Ricijaš, N., Glavak-Tkalić, R. (2014): Informed consent as a requirement for probation work with (in)voluntary clients: Probationers' and probation officers' perspectives. European Journal of Probation. 6 (3). 260-277.

Šimpraga, D. (2015): Žene pod nadzorom probacijske službe. Prezentirano 4. studenoga na Okruglom stolu "Stanje prava zatvorenica u hrvatskom pravosudnom sustavu" u organizaciji Udruge RODA, u okviru VOX Feminae Festivala.

Šimpraga D, Maloić S, Ricijaš N. (2014): Croatia. In: Probation in Europe (updated edition). http:// cep-probation.org/. (Preuzeto 20.6.2015.)

Šimpraga, D., Vukota, Lj. (2010): Probni projekt Uvjetni otpusti zatvorenika. Hrvatski ljetopis za kazneno pravo i praksu. 17 (2). 813-817.

Šućur, Z., Žakman-Ban, V. (2005): Značajke života i tretmana žena u zatvoru. Društvena istraživanja. 6 (80). 1055 - 1079.

Taxman, F. S. (2014): Second Generation of RNR: The Importance of Systemic Responsivity in Expanding Core Principles of Responsivity. Federal Probation. 78 (2). 32-40.

Taxman, F. S., Thanner, M., Weisburd, D. (2006): Risk, Need, And Responsivity (RNR): It All Depends. Crime \& Delinquency. 52(1). 28-51.

Ugwudike, P., Raynor, P. (2013): Conclusion: What Works in Offender Compliance. U: Ugwudike, P., Raynor, P. (ur.), What Works in Offender Compliance. Basingstoke. Palgrave Macmillan. 332-350.

Vrselja, I., Sučić, I., Franc, R. (2009). Rizična i antisocijalna ponašanja mlađih adolescenata i privrženost školi. Društvena istraživanja. 18 (4). 739-762.

Zakon o kaznenom postupku. Narodne novine, br. 152/08, 76/09, 80/11, 121/11, 91/12, 143/12, $56 / 13,145 / 13,152 / 14$.

Zakon o probaciji. Narodne novine, br. 153/09.

Zakon o probaciji. narodne novine, br. 143/12.

Ward, T. (2012): The Good Lives Model of Offender Rehabilitation: Basic Assumptions, Aetiological Commitments, and Practice Implications. U: McNeill, F., Raynor, P., Trotter, C. (ur.): Offender Supervision: New directions in theory, research and practice. Routledge. Abingdon. 41-46.

Ward, T., Fortune, C. (2013): The Good Lives Model: Aligning Risk Reduction with Promoting Offenders' Personal Goals. European Journal of Probation. 5 (2). 29-46.

Ward, T., Mann, R. E., Gannon, T. A. (2007): The good lives model of offender rehabilitation: Clinical implications. Aggression and Violent Behavior. 12 (1). 87-107.

Ward, T., Melser, J., Yates, P. M. (2007): Reconstructing the Risk-Need-Responsivity Model: A theoretical elaboration and evaluation. Aggression and Violent Behavior. 12. 208228.

Willis, G. M., Yates, P. M., Gannon T. A., Ward, T. (2013): How to Integrate the Good Lives Model Into Treatment Programs for Sexual Offending: An Introduction and Overview.

Sexual Abuse. 25 (2). 123-142. 
Snježana Maloić: Dominantna načela i modeli tretmanskog rada s punoljetnim počiniteljima kaznenih djela...

Wood, J., Kade C., Sidhu, M. (2009): What works for offender and staff: Comparing two multiagency approaches to offender resettlement. Psychology, Crime and Law. 15 (7). 661-678. 